\title{
CONTAM88 Building Input Files for Multi-Zone Airflow and Contaminant Dispersal Modeling
}

Jin B. Fang

Andrew K. Persily

Building and Fire Research Laboratory

Gaithersburg, Maryland 20899

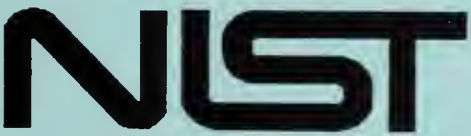

United States Department of Commerce ology Administration

QC al Institute of Standards and Technology 



\section{CONTAM88 Building Input Files for Multi-Zone Airflow and Contaminant Dispersal Modeling}

Jin B. Fang

Andrew K. Persily

June 1994

Building and Fire Research Laboratory

National Institute of Standards and Technology

Gaithersburg, MD 20899

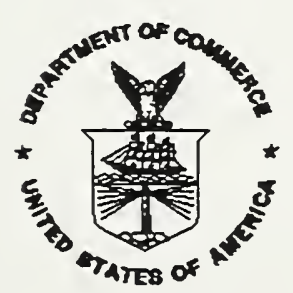

U.S. Department of Commerce

Ronald H. Brown, Secretary

Technology Administration

Mary L. Good, Under Secretary for Technology

National Institute of Standards and Technology

Arati Prabhakar, Director 



\begin{abstract}
Input files for the multi-zone airflow and contaminant dispersal computer program CONTAM88 are described for four large buildings. The files were developed for a twelve-story multi-family residential building, a five-story mechanically-ventilated office building with an atrium, a seven-story mechanically-ventilated office building with an underground parking garage, and a one-story school building. The physical characteristics of each building and its idealization as a multi-zone airflow system are described. These input files enable a user to employ CONTAM88 to study airflow and contaminant dispersal in these large buildings without developing building idealizations and inputting them into CONTAM88. Results of selected computer simulations are presented to demonstrate the effects of wind speed, indoor-outdoor temperature difference, and the percentage of outdoor air intake in the supply air on air change rates and interzonal airflows for these four buildings. Appendices are also included that contain a building component leakage database useful in multi-zone airflow modeling and updated information on the use of CONTAM88.
\end{abstract}

Key words : airflow modeling, building technology, computer modeling, contaminant dispersal, infiltration, modeling, ventilation. 



\section{TABLE OF CONTENTS}

ABSTRACT

1. INTRODUCTION

2. CONTAM88

3. BUILDING DESCRIPTIONS

3.1 Apartment Building 3

3.2 Office Building No. 1

3.3 Office Building No. 2

3.4 School Building 9

4. AIRFLOW SIMULATIONS 10

4.1 Apartment Building 11

4.2 Office Building No. 1

4.3 Office Building No. 2

$\begin{array}{lll}4.4 & \text { School Building } & 14\end{array}$

$\begin{array}{ll}\text { 5. SUMMARY } & 14\end{array}$

$\begin{array}{lr}\text { 6. REFERENCES } & 15\end{array}$

\section{APPENDICES}

A. Building Component Air Leakage Database 33

B. Sample Building Documentation File 41

C. Modeling Ventilation Systems with CONTAM88 49

D. Errata Sheet for CONTAM88 User's Manual 51 



\section{INTRODUCTION}

Infiltration and exfiltration of air through exterior envelopes and interzone airflow rates in buildings affect whole building ventilation rates, outdoor airflow rates to individual rooms, concentration levels of airborne contaminants, heating and cooling loads, and smoke movement in the event of a fire. Air movement and convective contaminant transport within multizone buildings are caused by pressure differences across openings in exterior walls and in partitions between individual zones. These pressure differences are caused by wind, thermal buoyancy and mechanical ventilation system airflows. For a building with known air leakage characteristics and ventilation system airflows under given weather conditions and pollutant source strengths, multi-zone airflow and contaminant transport models can predict the airflow and pollutant transport rates from one zone to another, or to the outside, and the contaminant levels in each zone.

Several models have been developed for predicting airflow, contaminant dispersal and fire-induced smoke movement in multi-zone buildings. Reviews of these multizone airflow and contaminant dispersal models are given in references 1 through 5 . These models use a network approach to obtain a set of nonlinear equations derived from a mass balance at each node and an iterative solution technique based on the Newton-Raphson method to solve for the pressure at each node. These pressures are then used to calculate the steady-state airflow rates to and from each zone based on the given leakage values. Using these airflow rates, pollutant source strengths and information on other pollutant transport mechanisms, some of these programs can also calculate contaminant concentrations in each building zone.

Multi-zone airflow models fully account for the complexity of infiltration and ventilation airflows in multi-zone buildings. These models can be used to understand air movement in multi-story buildings, to predict interzonal airflow patterns and zonal contaminant concentration levels, and to evaluate the performance of the building ventilation systems under different operating conditions. Knowledge of air leakage is also important in estimating the effectiveness of interior doors and walls as barriers to contaminants or smoke flow and in designing contaminant or smoke control systems. Modeling can also be useful to designers, builders, and code enforcement officials to predict whether the performance of a building will comply with fire, energy and indoor air quality codes and standards.

Multi-zone airflow models require information on the building being modeled including physical dimensions of the building, airflow resistances of the airflow paths, the configuration of mechanical ventilation systems, ventilation system airflow rates, wind pressure coefficients on the building facade, and ambient weather data. Contaminant dispersal analysis requires additional information including contaminant source strengths, source removal rates from indoor sinks, filter efficiencies and outdoor contaminant concentrations. However, when performing multi-zone airflow and contaminant dispersal analysis for a given building, there is generally only limited information available on the required inputs. Also, it is generally impractical to include all building zones, leakage openings, ventilation system components, and facade details affecting wind pressure distribution when modeling airflow in multi-zone buildings. However, valuable modeling exercises are still possible based on available information and a less than complete idealization of the building. An idealization of a multi-zone building refers to its 
representation as a multi-zone airflow system in a manner that captures the important features of the building and the airflow phenomena being studied. The idealization of a multi-zone building depends on the building layout, the ventilation system configuration and the objective of the modeling effort. A very complex building need not be modeled to include every building zone and leakage path, and in many situations it can be idealized as a much simpler system with a smaller number of zones. Building idealization for airflow modeling has not received a great deal of attention in the literature on airflow modeling, and general rules are not yet available to guide the modeler.

The objective of this report is to present several input files for the multi-zone airflow and contaminant dispersal model CONTAM88 [6]. Documentation and sample runs are provided for four multi-zone buildings including a twelve-story apartment building, a fivestory mechanically ventilated office building with an atrium, a seven-story mechanically ventilated office building with an underground parking garage, and a one-story school building. This report contains three main sections. The first section describes the computer program CONTAM88 and its companion program NBSAVIS, including the assumptions employed, the quantities it calculates and the inputs required. The physical characteristics of the four buildings and their multi-zone idealizations in the model are described in the next section. The third section presents sample simulation results for the four buildings. The results show the effects of wind speed, inside-outside temperature difference, and percent outdoor air intake rate on the calculated building air change rates. The report also includes the following appendices: A) a building component air leakage database for large commercial buildings; B) a sample building documentation file describing in detail the information contained in a building description file created with NBSAVIS; C) a discussion of how CONTAM88 is used to model ventilation systems; and, D) an errata sheet for the CONTAM88 user's manual [6].

\section{CONTAM88}

CONTAM88 was developed at NIST to enable multi-zone airflow and contaminant dispersal modeling in buildings [6]. This model assumes that a building can be idealized as a number of well-mixed zones that exchange air with each other and the outdoors through air leakage paths and ventilation systems. The computer code predicts air movement and contaminant concentration levels within a multizone building given the leakage characteristics of the openings to the outdoors and between zones, ventilation system airflow rates, weather conditions, contaminant sources and sinks, and wind pressure coefficients for the building exterior surfaces. Building surface wind pressure coefficients, if not given, can also be specified by a default algorithm within the code. The code is a combination of two previously developed programs: AIRMOV $[7,8]$ that performs network airflow analysis, and CONTAM87 [9] that simulates contaminant dispersal in multi-zone systems. The CONTAM88 manual [6] describes the airflow and contaminant dispersal theory employed in the program. Airflow between zones are represented as either openings or fans. Openings are described by a flow coefficient, which can be derived from a leakage area, and by a pressure exponent. 
A companion program to CONTAM88, called NBSAVIS, is a menu-driven preprocessor for creating building descriptions and data input files used by CONTAM88. The building description files contain all of the required input information on the building and have the file extension.DSC. NBSAVIS uses the building description files to create a series of input files, which are in turn used by CONTAM88 in the airflow and contaminant dispersal calculations. The input files are described in reference 6 , and the individual files contain information on the building zones, the leakage paths, ventilation system airflow rates and other inputs. These input files are used to calculate the airflow rates and contaminant concentration levels in buildings using the CONTAM88 program in conjunction with a weather data file and a program parameter file. The CONTAM88 code is capable of calculating steady-state airflow rates and both steady-state and transient contaminant concentrations.

\section{BUILDING DESCRIPTIONS}

This section describes the four buildings for which the input files were developed and how they were idealized in the building description files. The building description files themselves are described in detail in a text file with the extension.DOC. These .DOC files are not used by the CONTAM88 program, but are useful for documenting the details of the building input files. A sample .DOC file is presented in Appendix B.

\subsection{Apartment Building}

An apartment building consisting of twelve-stories and a basement is described in the building description file APART.DSC and the accompanying documentation file APART.DOC. This building description is based on a simplified building representation employed to model air and radon transport in a multi-story residential building [10]. The apartment building has horizontal dimensions of $30 \mathrm{~m}$ by $22.5 \mathrm{~m}$, a ceiling height of $2.5 \mathrm{~m}$ on each floor, a roof height of $30.5 \mathrm{~m}$ above grade, and a basement $2 \mathrm{~m}$ below grade. A typical floor plan and an elevation of this building are shown in Figures 1 and 2.

Each typical story (second through twelfth floors) of the building has four apartments, with two on each side of a central hall. The first floor contains a large lobby with a main entrance at the center of the west exterior wall and two apartment units on the east side. The basement has no interior partitions, except for the walls of the stair and elevator shafts. The building has an elevator shaft and a stairwell located at the ends of the hall. Both the elevator and stairwell shafts extend from the basement to the roof and have horizontal dimensions of $2.5 \mathrm{~m}$ by $2 \mathrm{~m}$. The hall is $26 \mathrm{~m}$ by $2.5 \mathrm{~m}$. Closed doors connect the hall to each apartment, and the halls and basement to the elevator and stairwell shafts. The shafts are modeled as a series of vertically-connected single-story zones. These shaft zones are connected by openings with a leakage area equal to the cross-sectional area of the shafts. Other models are available that account for the airflow resistance within the shafts [16]. The use of these other models is more critical when there are large airflow rates in the shafts, such as during the operation of smoke control systems. Exterior doors are located at the roof levels of the stairwell and elevator shafts. There are four windows on the long wall and three on the short wall of each apartment. 
Another building description file for the apartment building, referred to as APARTEX.DSC, was created by adding a $47 \mathrm{~L} / \mathrm{s}$ exhaust fan to each apartment. The file APARTEX.DOC documents the inputs to this building description file.

The leakage areas of the exterior and interior walls, the windows, the exterior and interior doors, and the joints between the walls and the floor, and the walls and the ceiling, are based on the data listed in Appendix $\mathrm{A}$ of this report and information from the previous modeling study of this building [10]. The leakage values used for various building components are as follows :

Exterior walls

Exterior doors

Main

Elevator

Stairway

Windows

Apartment

Basement

Interior walls

Apartment

Elevator shaft

Stair shaft

Shaft

Interior floors

Interior doors

Apartment

Elevator

Stairway

\section{$3.0 \mathrm{~cm}^{2} / \mathrm{m}^{2}$}

$58 \mathrm{~cm}^{2}$

$29 \mathrm{~cm}^{2}$

$29 \mathrm{~cm}^{2}$

$7.5 \mathrm{~cm}^{2}$

$1.35 \mathrm{~cm}^{2}$

$2.0 \mathrm{~cm}^{2} / \mathrm{m}^{2}$

$5.0 \mathrm{~cm}^{2} / \mathrm{m}^{2}$

$5.0 \mathrm{~cm}^{2} / \mathrm{m}^{2}$

$10000 \mathrm{~cm}^{2} / \mathrm{m}^{2}$

$0.5 \mathrm{~cm}^{2} / \mathrm{m}^{2}$

$75 \mathrm{~cm}^{2}$

$150 \mathrm{~cm}^{2}$

$150 \mathrm{~cm}^{2}$

The leakage area of $10000 \mathrm{~cm}^{2} / \mathrm{m}^{2}$, referred to a "shaft" under "Interior Walls," is the leakage between the single-story shaft zones of the elevator and stair shafts. The leakage areas at the wall-ceiling and wall-floor joints in the exterior walls of the apartments are assumed to equal to $2.5 \mathrm{~cm}^{2} / \mathrm{m}$ of joint length. All leakage areas are based on a reference pressure of $4 \mathrm{~Pa}$ and a discharge coefficient of 1.0. All leakage paths are characterized by a pressure exponent of 0.6 . The representation of this apartment building consists of 87 zones and 1233 openings.

Modifications to the input file for the apartment building can be made to study the effects of various parameters such as the tightness of exterior walls, leakage characteristics of interior partitions, and the exhaust airflow rate on the building air change rate, interzone air movement and contaminant dispersal. These options for airflow analysis are accomplished by changing the corresponding data contained in the building description files APART.DSC or APARTEX.DSC within the program NBSAVIS. 


\subsection{Office Building No. 1}

A seven-story mechanically ventilated office building with an atrium is described in the building description file OFF1-100.DSC and the accompanying documentation file OFF1100.DOC. This building is based on an office building located in Overland, Missouri that was the subject of a study of building ventilation and indoor air quality [12,13]. A detailed description of the building, including floor plans for all levels, is given in reference 12 .

The building consists of five floors, levels 1 through 5, located above grade and two floors, levels B1 and B2, below grade. Schematic floor plans of level-B2 and level-5 are shown in Figures 3 and 4, respectively. The main entrance of the building is located on the first floor, and a penthouse is situated on the south corner of the roof. The building is square in shape and has a square atrium in its center extending from the first floor to the roof. The building has overall dimensions of $74.4 \mathrm{~m}$ on a side, a ceiling height of $3.35 \mathrm{~m}$ on each floor, a total floor area of about $32,500 \mathrm{~m}^{2}$, and a volume of about $122,000 \mathrm{~m}^{3}$. Stairways are located in each corner of the building, and there are six passenger elevators and a freight elevator located in the south corner. A detailed description of the building, including floor plans for all levels, is given in reference 12 .

The building has a decentralized ventilation system with two air handling systems serving each floor. Each of these variable air volume air handling systems has a supply airflow capacity of $8.7 \mathrm{~m}^{3} / \mathrm{s}$ on levels 1 through 5 . The supply air capacity on each side of levels $\mathrm{B} 1$ and $\mathrm{B} 2$ and in the atrium is $6.4 \mathrm{~m}^{3} / \mathrm{s}$. Two toilet exhaust fans are located on the roof and serve each floor through a common exhaust duct. These fans operate with a combined exhaust airflow rate of $8.6 \mathrm{~m}^{3} / \mathrm{s}$. Return air from the occupied spaces flows through a return air plenum above the suspended ceiling and back to the air handlers where it is either recirculated into the supply air or exhausted to the outdoors.

The following air leakage values were used in the building description file for this building. They are all based on a reference pressure of $4 \mathrm{~Pa}$, a discharge coefficient of 1.0 , and a pressure exponent of 0.6 .

Exterior walls

$\begin{array}{ll}\text { Opaque } & 5.2 \mathrm{~cm}^{2} / \mathrm{m}^{2} \\ \text { Window } & 5.2 \mathrm{~cm}^{2} / \mathrm{m}^{2} \\ \text { Penthouse } & 7.8 \mathrm{~cm}^{2} / \mathrm{m}^{2}\end{array}$

Exterior doors

Main $\quad 58 \mathrm{~cm}^{2}$

Penthouse $\quad 29 \mathrm{~cm}^{2}$

Interior walls

Ceiling

$35 \mathrm{~cm}^{2} / \mathrm{m}^{2}$

Atrium

$5.0 \mathrm{~cm}^{2} / \mathrm{m}^{2}$

Elevator

$4.0 \mathrm{~cm}^{2} / \mathrm{m}^{2}$

Stairway

$2.0 \mathrm{~cm}^{2} / \mathrm{m}^{2}$

Floor

$0.4 \mathrm{~cm}^{2} / \mathrm{m}^{2}$

Shaft

$10000 \mathrm{~cm}^{2} / \mathrm{m}^{2}$ 
Interior doors

$\begin{array}{ll}\text { Passenger elevator } & 200 \mathrm{~cm}^{2} \\ \text { Stairway } & 174 \mathrm{~cm}^{2} \\ \text { Freight elevator } & 430 \mathrm{~cm}^{2}\end{array}$

The leakage values for the opaque and window exterior walls are based on the results of a whole building pressure test of the building on which the building description file was based [12]. A leakage area of $40 \mathrm{~cm}^{2}$ is assumed to exist for openings at the top of the elevator shaft in the penthouse for the elevator cables. The stairway and elevator shafts are modeled by a series of vertically-connected zones, one for each floor. These shaft zones are connected by an opening with a leakage area equal to the cross-sectional area of the shaft using the "Shaft" leakage value from the list given above. The space on each building floor is modeled as two zones, one below the suspended ceiling and another above the suspended ceiling. The leakage area of the suspended ceiling given above is $35 \mathrm{~cm}^{2} / \mathrm{m}^{2}$. The leakage area of the interior walls of the atrium is $5.0 \mathrm{~cm}^{2} / \mathrm{m}^{2}$. This office building is represented by 66 zones and 746 openings.

The mechanical ventilation system in this building is modeled using the ventilation system model described in Appendix C. Each of the fifteen air handling systems (two per floor plus the atrium system) is modeled within CONTAM88 as two HVAC systems, one supply system and one return system. Supply airflow rates are specified from each supply air handling system to the zone below the suspended ceiling. Return airflow rates are specified from the zone above the suspended ceiling to each supply system in order to account for recirculated return air. Another return airflow rate is specified from the zone above the ceiling to the return HVAC system to account for return air that is exhausted to the outdoors. For the supply systems, any difference between the airflow rate of recirculated return air and supply air is made up with outdoor air intake. By adjusting the airflow rates of return air to the supply and return HVAC systems, one can modulate the outdoor airflow rate brought into the building.

Three levels of outdoor air intake were applied to Office Building No. 1: 100\% outdoor air intake, $50 \%$ outdoor air intake, and the minimum design level of outdoor air intake. The airflow rates of supply, recirculation and return air for these three cases are given in Table 1. This table also contains the exhaust airflow rate from each floor associated with the toilet exhaust. The three separate cases of outdoor air intake are contained in the three building description files: OFF1-100.DSC, OFF1-050.DSC and OFF1-MIN.DSC.

Office Building No. 1 can be studied at other outdoor air intake rates and for other values for the various input parameters by modifying the building description files using NBSAVIS. 


\subsection{Office Building No. 2}

Office Building No. 2 is a seven-story, mechanically ventilated office building with one story below grade and a two-story underground parking garage. The building is described in the building description file OFF2-100.DSC and the documentation file OFF2100.DOC. This building is based on an office building in Portland, Oregon that was the subject of a study of ventilation and indoor air quality $[14,15]$. A schematic floor plan of the building and an elevation of the building are shown in Figures 5 and 6, respectively. The building has a main entrance and reception area located on the first floor and a loading dock on the first below-grade level. An underground parking garage is located on the next two below-grade levels. The building mechanical equipment is located in a rooftop penthouse.

The building has a conditioned floor area of about $42,900 \mathrm{~m}^{2}$ and a building volume of approximately $183,600 \mathrm{~m}^{3}$. Eight passenger elevators and a freight elevator are located on the east side of the building. Stairways are located on both the east and west sides of the building that provide access to all ten building floors. Another stairway is located on the west side of the building and links only the seven above-grade levels. These stairways are connected to the occupied areas of the building by doors. The two-story parking garage is connected to the occupied spaces by two stairways and four passenger elevators.

There are three variable air volume air handlers in the penthouse mechanical room that serve all seven above-grade floors. These three air handlers serve the east, west and center of the building. The design supply air capacities of the HVAC systems are $50.2 \mathrm{~m}^{3} / \mathrm{s}$, $43.5 \mathrm{~m}^{3} / \mathrm{s}$ and $51.2 \mathrm{~m}^{3} / \mathrm{s}$ for the center, east and west zones of the building. There are six smaller air handling units located on and serving the B1 level, with a total supply air capacity of $25.1 \mathrm{~m}^{3} / \mathrm{s}$. Two toilet exhaust fans are located on the roof and serve each floor through a common duct. The capacity of each of these toilet exhaust fans is $0.83 \mathrm{~m}^{3} / \mathrm{s}$ per floor for levels B1 through 7. The underground garage has four exhaust fans with an airflow rate of $54.3 \mathrm{~m}^{3} / \mathrm{s}$ air per garage level.

The building component leakage values used in Office Building No.2 are as follows:

Exterior walls

Opaque

Window

Penthouse

Exterior doors

Main

Penthouse

Loading dock

Garage

Interior walls

Ceiling

Elevator

Stairway

Floor

Shaft
$2.0 \mathrm{~cm}^{2} / \mathrm{m}^{2}$

$2.0 \mathrm{~cm}^{2} / \mathrm{m}^{2}$

$4.0 \mathrm{~cm}^{2} / \mathrm{m}^{2}$

$31 \mathrm{~cm}^{2}$

$31 \mathrm{~cm}^{2}$

$58 \mathrm{~cm}^{2}$

$150000 \mathrm{~cm}^{2}$

$35 \mathrm{~cm}^{2} / \mathrm{m}^{2}$

$4.0 \mathrm{~cm}^{2} / \mathrm{m}^{2}$

$2.0 \mathrm{~cm}^{2} / \mathrm{m}^{2}$

$0.4 \mathrm{~cm}^{2} / \mathrm{m}^{2}$

$10000 \mathrm{~cm}^{2} / \mathrm{m}^{2}$ 
Interior doors

$\begin{array}{ll}\text { Passenger elevator } & 200 \mathrm{~cm}^{2} \\ \text { Stairwell } & 200 \mathrm{~cm}^{2} \\ \text { Freight elevator } & 300 \mathrm{~cm}^{2}\end{array}$

These leakage areas are all based on a reference pressure of $4 \mathrm{~Pa}$, a discharge coefficient of 1.0 , and a pressure exponent of 0.6 .

The stairway and elevator shafts are modeled by a series of vertically-connected zones, one for each floor. These shaft zones are connected by an opening with a leakage area equal to the cross-sectional area of the shaft using the "Shaft" leakage value from the list above. The space on each building floor is modeled as two zones, one below the suspended ceiling and another above the suspended ceiling. The parking garage is modeled as two zones, one for each level, which are horizontally divided by a floor. The upper level of the garage has a large door open to the exterior (Exterior door, Garage) and is connected to the lower level through a $7.6 \mathrm{~m}$ by $3.1 \mathrm{~m}$ opening in the floor. The representation of this office building contains 77 zones and 660 openings.

The mechanical ventilation system in this building is modeled using the ventilation system model in CONTAM88 described in Appendix C. Each of the three main air handling systems is modeled as two HVAC systems, one supply and one return system. All of the air handlers serving level B1 are modeled with another supply and return system. Supply airflow rates are specified from each supply air handling system to the zone below the suspended ceiling. Return airflow rates are specified from the zone above the suspended ceiling to each supply system in order to account for recirculated return air. Another return airflow rate is specified from the zone above the ceiling to the return HVAC system to account for return air that is exhausted to the outdoors. For the supply systems, any difference between the airflow rate of recirculated return air and supply air is made up with outdoor air intake. By adjusting the airflow rates of return air to the supply and return HVAC systems, one can modulate the outdoor airflow rate brought into the building.

Three levels of outdoor air intake were applied to Office Building No. 2: $100 \%$ outdoor air intake, $50 \%$ outdoor air intake, and the minimum design level of outdoor air intake. The airflow rates of supply, recirculation and return air for these three cases are given in Table 2. This table also contains the exhaust airflow rate from each floor associated with the toilet exhaust and the exhaust airflow rates from each floor of the garage. The three separate cases of outdoor air intake are described in the three building description files: OFF2-100.DSC, OFF2-050.DSC and OFF2-MIN.DSC.

Office Building No. 2 can be studied at other outdoor air intake rates and for other values for the various air leakage parameters by modifying the building description files using NBSAVIS. 


\subsection{School Building}

A mechanically ventilated school building with a central courtyard is described in the building description file SCHOOL.DSC and the accompanying documentation file SCHOOL.DOC. This building is based on an elementary school building located in Montgomery County, Maryland. It consists of classrooms, conference rooms, offices, storage rooms, corridors, toilets, a kitchen, an all purpose room and a boiler room. A floor plan of the school is shown in Figure 7. The numbers in the figure refer to the zone numbers in the SCHOOL.DSC file. The building has a $12.5 \mathrm{~m} \mathrm{x} 32.8 \mathrm{~m}$ courtyard and overall dimensions of approximately $66 \mathrm{~m}$ by $72 \mathrm{~m}$. The total floor area of the building is about $3,990 \mathrm{~m}^{2}$, and the building volume is approximately $15,050 \mathrm{~m}^{3}$.

The ventilation system in this building consists of a combination of unit ventilators, supply air handlers and ducted and unducted exhaust fans. Forty-three individual unit ventilators are mounted in the exterior walls of the classrooms and several office and storage rooms. The design airflow rates of these unit ventilators vary among the rooms, and the total supply airflow capacity of all the unit ventilators is $16.5 \mathrm{~m}^{3} / \mathrm{s}$. An air handler with a supply airflow capacity of $0.95 \mathrm{~m}^{3} / \mathrm{s}$ serves the general office space. The building also has nine ducted exhaust systems that serve various combinations of rooms in the building with a total exhaust airflow capacity of $8.43 \mathrm{~m}^{3} / \mathrm{s}$. There are sixteen unducted, local exhaust fans that serve the kitchen, general office space and conference/storage rooms, with a combined capacity of $3.87 \mathrm{~m}^{3} / \mathrm{s}$. The total supply airflow capacity of the building is $17.5 \mathrm{~m}^{3} / \mathrm{s}$, which corresponds to an air change rate of 3.92 air changes per hour (ach). The outdoor airflow rate is $4.38 \mathrm{~m}^{3} / \mathrm{s}$, corresponding to $25 \%$ outdoor air intake, which equals 4.4 (ach). The total exhaust airflow capacity is $12.5 \mathrm{~m}^{3} / \mathrm{s}$. Therefore, there is an excess of mechanical supply over exhaust in this building.

The building component leakage values used in the school building are as follows:

Exterior walls

$\begin{array}{ll}\text { Masonry } & 2.9 \mathrm{~cm}^{2} / \mathrm{m}^{2} \\ \text { Window } & 2.0 \mathrm{~cm}^{2} / \mathrm{m}^{2}\end{array}$

Exterior doors

Hollow metal $29 \mathrm{~cm}^{2}$

Windows

Hollow metal with glass $29 \mathrm{~cm}^{2}$

$\begin{array}{ll}\text { Standard } & 3.8 \mathrm{~cm}^{2} \\ \text { All purpose room } & 7.1 \mathrm{~cm}^{2} \\ \text { Kitchen } & 4.9 \mathrm{~cm}^{2} \\ \text { Frame Type A } & 3.9 \mathrm{~cm}^{2} \\ \text { Frame Type B } & 2.4 \mathrm{~cm}^{2} \\ \text { Frame Type C } & 2.1 \mathrm{~cm}^{2} \\ \text { Frame Type D } & 1.2 \mathrm{~cm}^{2} \\ \text { Frame Type E } & 4.8 \mathrm{~cm}^{2} \\ \text { Frame Type F } & 1.4 \mathrm{~cm}^{2} \\ \text { Office } & 9.3 \mathrm{~cm}^{2}\end{array}$


Interior walls

$\begin{array}{ll}\text { Masonry, } 0.31-\mathrm{m} & 2.0 \mathrm{~cm}^{2} / \mathrm{m}^{2} \\ \text { Masonry, 0.15-m } & 2.0 \mathrm{~cm}^{2} / \mathrm{m}^{2} \\ \text { Masonry, 0.15-m with gap } & 2.0 \mathrm{~cm}^{2} / \mathrm{m}^{2} \\ \text { Partition, 0.08-m } & 1.9 \mathrm{~cm}^{2} / \mathrm{m}^{2} \\ \text { Passage-way or plenum wall } & 10000 \mathrm{~cm}^{2} / \mathrm{m}^{2} \\ \text { Ceiling } & 0.19 \mathrm{~cm}^{2} / \mathrm{m}^{2} \\ & \\ \text { Solid core wood with small glass } & 75 \mathrm{~cm}^{2} \\ \text { Solid core wood with large glass } & 75 \mathrm{~cm}^{2} \\ \text { Hollow metal } & 75 \mathrm{~cm}^{2}\end{array}$

These leakage areas are all based on a reference pressure of $4 \mathrm{~Pa}$, a discharge coefficient of 1.0 , and a pressure exponent of 0.6 .

The leakage values of the building components are based on the data presented in Appendix $\mathrm{A}$ of this report and information provided in references 10 and 11. There are two types of exterior walls in this building, opaque masonry walls and window walls, each with its own leakage coefficient. Two types of exterior doors are included in the building description file, but both are assumed to have the same leakage area. There are ten types of windows, including frame types $\mathrm{A}$ to $\mathrm{F}$ which are windows around doorways in the building. The leakage area of each is estimated based on the crack length of the windows.

In the building description file, the unit ventilators are modeled as a fixed outdoor flow rate to each individual room. The supply airflow to general office space (zone \#27) is also modeled as a fixed flow. The nine ducted exhaust systems are modeled as HVAC systems within the CONTAM88 program, with return vents located in each room served by the individual systems. The local exhaust fans serving the kitchen (zone \#19) and other rooms are modeled as fixed exhaust airflows.

The building description file SCHOOL.DSC contains 63 zones and 629 openings. The school building can be studied at other outdoor air intake rates and for other values for the various air leakage parameters by modifying the building description files using NBSAVIS.

\section{AIRFLOW SIMULATIONS}

This section presents the results of selected calculations of airflow rate in the four buildings using CONTAM88. The effects of weather conditions and the operation of exhaust fans in the individual apartments were examined for the apartment building. Building air change rates were calculated for three levels of outdoor air intake and a range of outdoor temperatures and wind speeds for the two office buildings. Air change rates were calculated for a range of weather conditions in the school building. The results of the airflow simulations are airflow rates through every opening in the exterior envelope and in interior partitions. CONTAM88 summarizes these airflow rates as infiltration, exfiltration, intake and exhaust rates for the whole building. The infiltration and exfiltration rates are totals of the airflow rates into and out of leaks in the exterior envelope. The total intake rate is the 
sum of the infiltration rate through the building envelope and the outdoor airflow rate into the building through the ventilation systems. The total exhaust rate is the sum of the exfiltration rate through the envelope and the airflow rate out of the building through mechanical exhaust systems and other air handlers. CONTAM88 also calculates the airflow rate to and from any pair of zones for which such an interzone airflow exists. The results are presented in this section as whole building infiltration and intake rates. In large buildings, there are many interzone airflow rates and it is difficult to present them in either graphical or tabular form. All of these airflow rates, however, are given in the CONTAM88 output files.

\subsection{Apartment Building}

Airflow rate calculations were performed in the twelve-story apartment building for a range of weather conditions. Calculations were also performed with a $47 \mathrm{~L} / \mathrm{s}$ (corresponding to $0.057 \mathrm{~kg} / \mathrm{s}$ ) exhaust fan in each apartment. Figure 8 shows the calculated airflow rates between each zone and the outdoors for the apartment building at a temperature difference of $20{ }^{\circ} \mathrm{C}$ and a wind speed of $0 \mathrm{~m} / \mathrm{s}$. Figure 9 shows the results with an exhaust fan operating in each apartment. In both figures, the flow rates between each type of zone (shaft, hall and apartment) and between each zone type and the outdoors are given in $\mathrm{kg} / \mathrm{s}$. The symmetry of these buildings, and the fact that the elevator and stair shaft leakage are identical, allows the results to be depicted in graphical form. As seen in Figure 8, the upward flow of air in the stair and elevator shafts due to the stack effect is a dominant mechanism for air movement within the building. Air flows into the shafts from the outdoors, basement, hallways and apartments for floors 1 through 6 , and out of the shafts into the outdoors, apartments and hallways on floors 7 and higher. Outdoor air infiltrates into the apartments on levels 1 through 10 (indicated by the outdoor-to-indoor arrows on the right side of Figure 8) and exfiltrates from the apartments on levels 3 through 12 (indicated by the indoor-to-outdoor arrows on the right side of the figure). Note that the existence of both infiltration and exfiltration in the apartments on floors 3 through 10 indicates that there is a local neutral pressure level between the ceiling and floor of each of these apartments.

Comparing Figures 8 and 9, it can be seen that the exhaust fans result in an overall reduction in the interior pressure of the building which leads to increased infiltration of outdoor air, decreased exfiltration, and shifting upward of neutral pressure levels. The location of the neutral pressure level for the shafts is indicated by a change in direction of the arrows on the left side of Figures 8 and 9. As indicated in Figure 8, without the exhaust fans the neutral pressure level of the shafts is between floors 6 and 7, but with the fans (Figure 9) it is raised to an elevation between floors 7 and 8.

With the exhaust fans operating the indoor-to-outdoor arrows on the right side of Figure 9 indicate airflow out of the apartments on floors 1 through 12 . For floors 1 through 7 this airflow is exclusively the specified exhaust airflow rate of $0.057 \mathrm{~kg} / \mathrm{s}$, but on floors 8 through 12 additional outflow due to leakage is indicated by the fact that the airflow rates are greater than $0.057 \mathrm{~kg} / \mathrm{s}$. For example, on floor 11 the total airflow rate out of the apartments of $0.067 \mathrm{~kg} / \mathrm{s}$ includes the exhaust component and an exfiltration component of $0.010 \mathrm{~kg} / \mathrm{s}$. The outdoor-to-indoor arrows on the right side of Figure 9 indicate that there is infiltration into the apartments on all floors of the building. 
For a temperature difference of $20^{\circ} \mathrm{C}$ and a wind speed of $0 \mathrm{~m} / \mathrm{s}$, the whole building air change rate is 0.16 air changes per hour (ach) without the exhaust fans operating and 0.38 ach with the exhaust fans. In both cases, these air change rates are due to outdoor air flowing into the building through leaks in the exterior envelope.

Whole building air change rates were predicted as a function of weather conditions in the apartment building, both with and without the exhaust fans operating. The range of weather conditions included indoor-outdoor temperature differences from $-10{ }^{\circ} \mathrm{C}$ to $30{ }^{\circ} \mathrm{C}$ in $5{ }^{\circ} \mathrm{C}$ increments, and wind speeds from 0 to $10 \mathrm{~m} / \mathrm{s}$ in $2 \mathrm{~m} / \mathrm{s}$ increments. The calculated air infiltration rates of the building with exhaust fans off and on are plotted against the inside-outside temperature difference for a variety of wind speeds in Figures 10 and 11, respectively. For a wind speed of $0 \mathrm{~m} / \mathrm{s}$, there is a significant dependence of infiltration on temperature difference for the case with no exhaust fans. At higher wind speeds or with the exhaust fans operating, temperature difference has little influence on the infiltration rate.

\subsection{Office Building No. 1}

Airflow rates were calculated for Office Building No. 1 for three cases of outdoor air intake and the same range of weather conditions that was applied to the apartment building. As described earlier, three building description files were developed for this building at $100 \%$ outdoor air intake, $50 \%$ outdoor air intake and minimum outdoor intake.

At an indoor-outdoor temperature difference of $20^{\circ} \mathrm{C}$ and a wind speed $0 \mathrm{~m} / \mathrm{s}$, the total outdoor air change rate was calculated to be $3.34,1.68$ and 0.66 ach respectively for outdoor air intake rates of $100 \%, 50 \%$ and minimum. These building air change rates are dominated by outdoor air intake by the mechanical ventilation systems. The air infiltration rate through the exterior envelope is only 0.03 ach in all three cases. The infiltration rate is small because the airflow rate of outdoor air into the building through the air handlers is significantly larger than the airflow rate out of the building through mechanical exhaust. This difference between the outdoor air intake and exhaust airflow rates causes the building to be at a positive pressure relative to the outdoors and limits the amount of envelope infiltration. The various mechanical ventilation airflow rates were input into the model such that the difference between the outdoor air intake and exhaust airflow rates were the same for all levels of outdoor air intake. In a real building, the airflow rates are unlikely to be controlled so precisely, and the outdoor air intake rates may be quite different from design and the infiltration rates may be much larger.

The building airflow rates were calculated at all three levels of outdoor air intake for the same values of wind speed and temperature difference as were applied to the apartment building. The predicted envelope infiltration rates of the whole building for the $100 \%$ intake case are plotted against the inside-outside temperature difference for six different wind speeds in Figure 12. In all cases, the envelope infiltration rates are very small, on the order of 0.1 air changes per hour. For low wind speeds, the infiltration rates increase with an increase in temperature difference. For high values of wind speeds, the relative strength of the stack effect diminishes as the wind pressures acting across the exterior surfaces dominate the temperature-induced pressures. As mentioned above, the predicted envelope infiltration rates are essentially independent of the level of outdoor air intake. 
Figure 13 shows the calculated values of the total outdoor air change rate of the building, infiltration plus air handler intake. The air change rates are plotted against indooroutdoor temperature difference for wind speeds of 0 and $8 \mathrm{~m} / \mathrm{s}$, for all three levels of outdoor air intake. As seen in the figure, the air change rate decreases slightly as the temperature difference increases (outdoor temperature decreases) because the specific volume of the outdoor air depends on temperature. Otherwise the air change rates have little dependence on weather.

The actual building on which Office Building No. 1 is based was subjected to tracer gas decay measurement of whole building air change rates [13]. The results of these measurements were air change rates of about 0.3 ach at minimum outdoor air intake and 2.6 ach at maximum outdoor air. The values predicted using CONTAM 88 with no wind and a $20^{\circ} \mathrm{C}$ temperature difference were 0.66 and 3.34 ach for minimum and $100 \%$ intake respectively. However, the predictions assume ideal control of the ventilation system airflow rates and are based on assumed values for many air leakage parameters. Also, it is not clear whether the maximum level of outdoor air intake for the building ventilation systems actually corresponds to $100 \%$ outdoor air intake. Given these limitations, however, the agreement between the measurements and predictions is fairly good.

\subsection{Office Building No. 2}

Airflow rates were calculated for Office Building No.2 for three cases of outdoor air intake and the same range of weather conditions that was applied to the other buildings. As described earlier, three building description files were developed for this building at $100 \%$ outdoor air intake, $50 \%$ outdoor air intake and minimum outdoor intake respectively.

At an indoor-outdoor temperature difference of $20^{\circ} \mathrm{C}$ and a wind speed $0 \mathrm{~m} / \mathrm{s}$, the total outdoor air change rate was calculated to be $3.12,1.56$ and 0.15 ach respectively for outdoor air intake rates of $100 \%, 50 \%$ and minimum. The envelope infiltration rate is less than 0.01 ach for $50 \%$ and $100 \%$ outdoor air intake, and 0.05 ach for minimum outdoor air intake. The infiltration rate is higher at the minimum condition because of differences in the balance of the outdoor air intake and the mechanical exhaust airflow rates at minimum intake as compared to the balance at the other two intake values.

The building airflow rates were calculated at all three levels of outdoor air intake for the same values of wind speed and temperature difference as were applied to the other buildings. The predicted envelope infiltration rates of the whole building for the $100 \%$ intake case are plotted against the inside-outside temperature difference in Figure 14. There is almost no dependence of the infiltration rate on temperature differences due to the dominance of mechanical flows.

Figure 15 shows a plot of calculated total air intake rates as a function of the indooroutdoor temperature difference. The total air intake rate is equal to the flow rate of outdoor air brought into the building by mechanical ventilation plus the air infiltration rate through building envelope. The air change rates at three levels of outdoor air intake are plotted against indoor-outdoor temperature difference for wind speeds of 0 and $10 \mathrm{~m} / \mathrm{s}$. As seen in the figure, the air change rate decreases as the temperature difference increases (outdoor 
temperature decreases) because the specific volume of the outdoor air depends on temperature.

The actual building on which Office building No. 2 is based was also subjected to tracer gas decay measurements of whole building air change rates [14]. The results of these measurements were air change rates of about 0.2 ach at minimum outdoor air intake and 2.6 ach at maximum outdoor air. The predicted values for Office Building No. 2 with no wind and a $20^{\circ} \mathrm{C}$ temperature difference were 0.15 and 3.12 ach for minimum and $100 \%$ outdoor air intake. As in the case of Office Building No. 1, these predictions assume ideal control of the ventilation system airflow rates and are based on assumed values for many air leakage parameters. Also maximum outdoor air intake in the actual building may not be $100 \%$ intake. The agreement between the measurements and predictions, especially at minimum outdoor air intake, are fairly good given the limitations of these predictions.

\subsection{School Building}

Airflow rates were calculated for the school building for the same range of weather conditions that was applied to the other buildings. Figure 16 is plot of the building infiltration rates against indoor-outdoor temperature difference for wind speeds of 0 and 10 $\mathrm{m} / \mathrm{s}$. These infiltration rates vary only slightly, from 1.76 to $2.02 \mathrm{ach}$, because the pressure differences caused by the operation of the mechanical ventilation system dominate the pressures from stack and wind. The stack pressures are particularly low in the building because it has only one story.

Figure 17 shows the calculated total intake rates of air into the building plotted against the indoor-outdoor temperature difference for wind speeds ranging from 0 to $10 \mathrm{~m} / \mathrm{s}$. The total air intake rate is equal to the sum of the flow rate of outdoor air brought into the building by mechanical ventilation plus the rate of outdoor air infiltration through the building envelope. The total air intake rate is relatively constant, but decreases with increasing indoor-outdoor temperature difference due to the change in air density with air temperature. The total air intake rate of the building is so stable because the outdoor air intake through the mechanical system dominates stack and wind induced infiltration.

\section{SUMMARY}

CONTAM88 input files are described for a twelve-story multi-family residential building, two multi-story office buildings with mechanical ventilation, and a one-story mechanically ventilated school building. These files describe each building as a multi-zone building airflow system as it was implemented in NBSAVIS for calculations with CONTAM88. The files provide users interested in performing multizone airflow and contaminant dispersal analysis with sample cases without having to develop the complex building representations. Selected computer simulations were performed to study the effects of various parameters such as operations of building ventilation systems, wind speed and indoor-outdoor temperature difference. 


\section{REFERENCES}

1. Feustel, H.E. and V.M. Kendon. 1985. "Infiltration Models for Multicellular Structures- A Literature Review." Energy and Buildings, 8, 123-136.

2. Feustel, H.E. and J. Dieris. 1992. "A Survey of Airflow Models for Multizone Structures." Energy and Buildings, 18, 79-100.

3. Austin, B.S., S.M. Greenfield, B.R. Weir, G.E. Anderson, and J.V. Behar. 1992. "Modeling the Indoor Environment." Environmental Science and Technology, 26(5), 851-858.

4. Haghighat, F. 1989. " Air Infiltration and Indoor Air Quality Models- A Review." International Journal of Ambient Energy, 10(3), 115-122.

5. Said, N. A. 1988. "A Review of Smoke Control Models." ASHRAE Journal, 30(4), 36-40.

6. Grot, R. A. 1991. "User Manual NBSAVIS CONTAM88." NISTIR 4585, National Institute of Standards and Technology, Gaithersburg, MD.

7. Walton, G. N. 1983. "A Computer Algorithm for Estimating Infiltration and Inter-Room Air Flows." NBSIR 83-2635, National Institute of Standards and Technology, Gaithersburg, MD.

8. Walton, G. N. 1984. "A Computer Algorithm for Predicting Infiltration and Interroom Airflows." ASHRAE Transactions, Vol. 90, Part 1B, 601-610.

9. Axley, J. 1988. "Progress Toward a General Analytical Method for Predicting Indoor Air Pollution in Buildings - Indoor Air Quality Modeling Phase III Report." NBSIR 88-3814, National Bureau of Standards, Gaithersburg, MD.

10. Persily, A. K. 1993. "Modeling Radon Transport in Multi-Story Residential Buildings." Modeling of Indoor Air Quality and Exposure, ASTM STP 1205, Niren L. Nagda, Ed., American Society for Testing and Materials, Philadelphia, PA, 226-242.

11. ASHRAE.1993. ASHRAE Handbook - Fundamentals, American Society of Heating, Refrigerating and Air-Conditioning Engineers, Atlanta, GA.

12. Persily, A. K., W. S. Dols, S. J. Nabinger, and S. Kirchner. 1991. "Preliminary Results of the Environmental Evaluation of the Federal Records Center in Overland Missouri." NISTIR 4634, National Institute of Standards and Technology, Gaithersburg, MD.

13. Persily, A. K., W. S. Dols, and S. J. Nabinger. 1992. "Environmental Evaluation of the Federal Records Center in Overland Missouri." NISTIR 4883, National Institute of Standards and Technology, Gaithersburg, MD. 
14. Grot, R. A., A. K. Persily, A. T. Hodgson, and J. M. Daisey. 1989. "Environmental Evaluation of the Portland East Federal Office Building Preoccupancy and Early Occupancy Results." NISTIR 89-4066, National Institute of Standards and Technology, Gaithersburg, MD.

15. Dols, W. S. and A. K. Persily. 1992. "A Study of Ventilation Measurement in an Office Building." NISTIR 4905, National Institute of Standards and Technology, Gaithersburg, MD.

16. Achakji, G. Y. and G. T. Tamura. 1988, "Pressure Drop Characteristics of Typical Stairshafts in High-Rise Buildings." ASHRAE Transactions, Vol. 94, Part 1, 1223-1237. 
Table 1. Ventilation System Airflow Rates (in $\mathrm{m}^{3} / \mathrm{s}$ per system) for Office Building No. 1

\section{HVAC SYSTEM}

Levels B1 and B2

Supply

Recirculation

Return

Levels 1 through 5

Supply

Recirculation

Return

Atrium

Supply

Recirculation

Return

All Floors

Toilet exhaust (per floor)
$100 \%$

6.43

0.0

5.79

8.67

0.0

7.80

6.43

0.0

5.79

6.43

3.22

2.57

8.67

4.34

3.46

8.67

6.96

0.84

1.23

1.23

1.23 
Table 2. Ventilation System Airflow Rates (in $\mathrm{m}^{3} / \mathrm{s}$ ) for Office Building No. 2

HVAC SYSTEM

Levels B3 and B2

Garage exhaust

$\begin{array}{llc}54.5 & 54.5 & 54.5 \\ 100 \% & 50 \% & \text { Minimum }\end{array}$

Level B1

Supply

25.1

25.1

25.1

Recirculation

0.0

12.6

25.0

Return

23.3

10.7

0.0

Level 1

Supply East

5.51

5.51

5.51

Recirculation East

0.0

2.75

5.28

Return East

4.74

1.99

0.0

Supply Center

7.31

7.31

7.31

0.0

3.66

7.04

Return Center

6.29

2.63

0.0

Supply West

8.84

8.84

8.84

0.0

4.42

8.51

Return West

7.60

3.18

0.0

Level 2

Supply East

5.42

5.42

0.0

2.71

Recirculation East

4.66

1.95

7.59

7.59

Supply Center

0.0

3.79

6.53

2.73

Return Center

9.74

9.74

0.0

Recirculation West

Return West

8.38

4.87

3.51

5.42

5.19

0.0

7.59

7.30

0.0

9.74

9.38

0.0

Levels 3 through 5 East

Supply

6.55

6.55

6.55

Recirculation

0.0

3.27

6.27

Return

5.63

2.36

0.0

Level 3 Center

Supply

7.36

7.36

7.36

Recirculation

0.0

3.68

7.09

Return

6.33

2.65

0.0 
Level 3 West

Supply

7.65

7.65

7.65

Recirculation

0.0

3.83

7.37

Return

6.58

2.75

0.0

Level 4 Center

Supply

7.87

7.87

7.87

Recirculation

0.0

3.94

7.58

Return

6.77

2.83

0.0

Levels 4 through 7 West

Supply

6.24

6.24

0.0

3.12

Recirculation

5.37

2.25

6.24

Return

6.02

0.0

Level 5 Center

Supply

7.17

7.17

0.0

3.59

7.17

6.17

2.58

6.91

Return

6.77

6.77

0.0

Level 6 East

Supply

0.0

3.39

5.83

2.44

6.77

6.49

Return

6.46

6.46

3.23

0.0

2.32

0.0

Levels 6 and 7 Center

Supply

5.55

6.46

Recirculation

.

6.16

6.16

3.08

5.30

2.22

6.16

Supply

Recirculation

Return

5.90

0.0

Floors B1 through 7

Toilet exhaust

0.79

0.79

0.79 


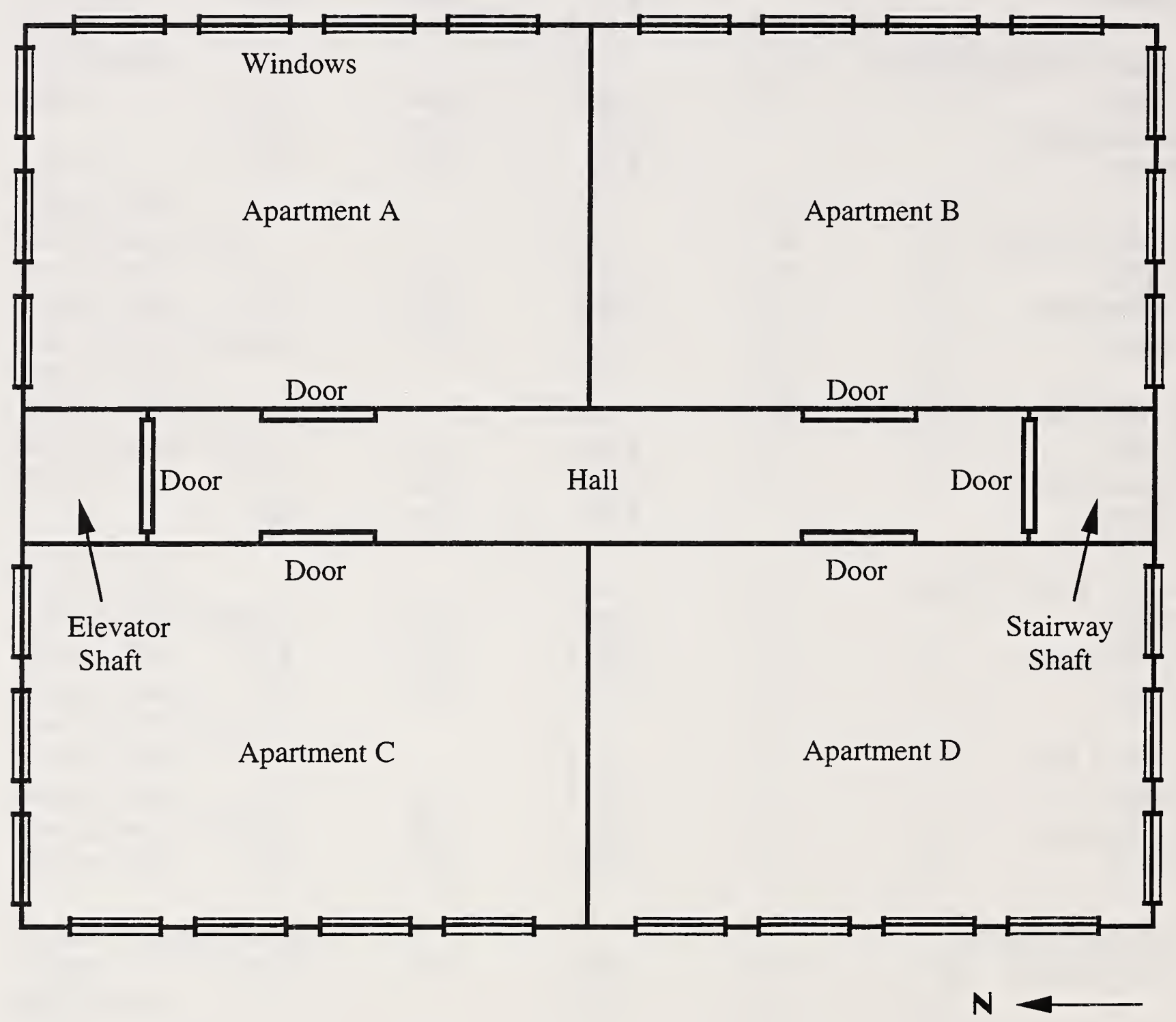

Figure 1 Typical Floor Plan of Apartment Building 


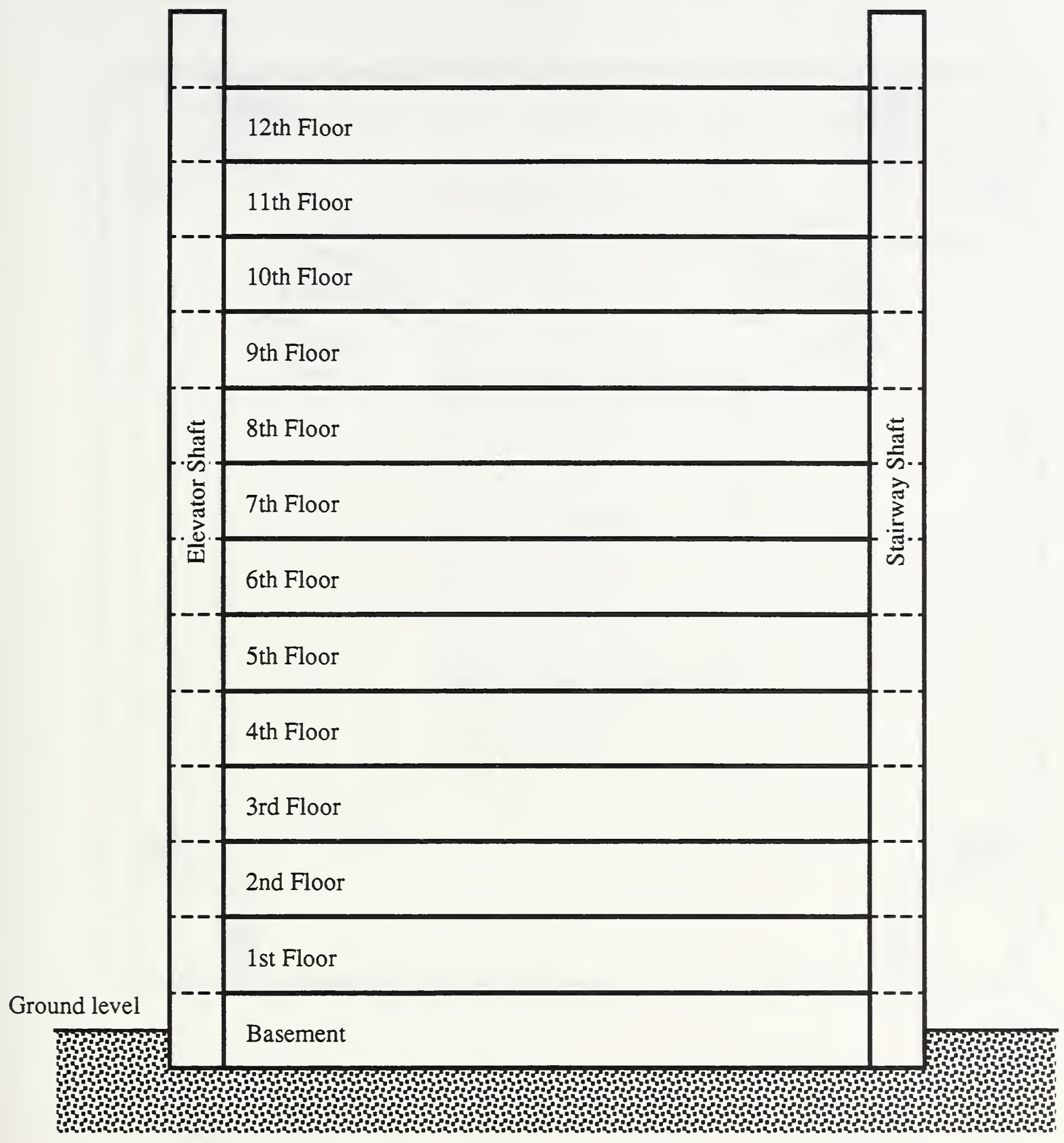

Figure 2 Elevation of Apartment Building 

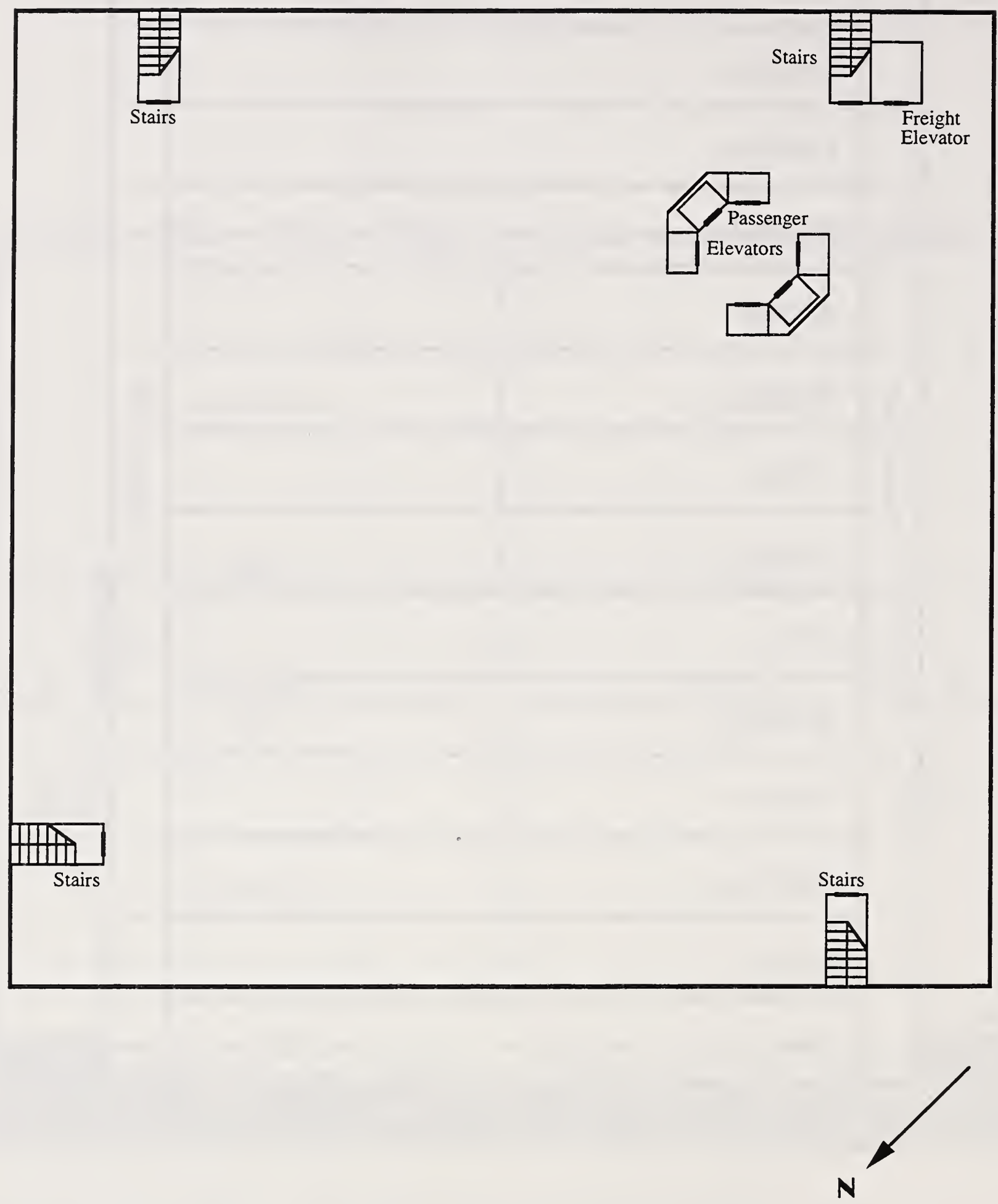

Figure 3 Level-B2 Floor Plan of Office Building No. 1 


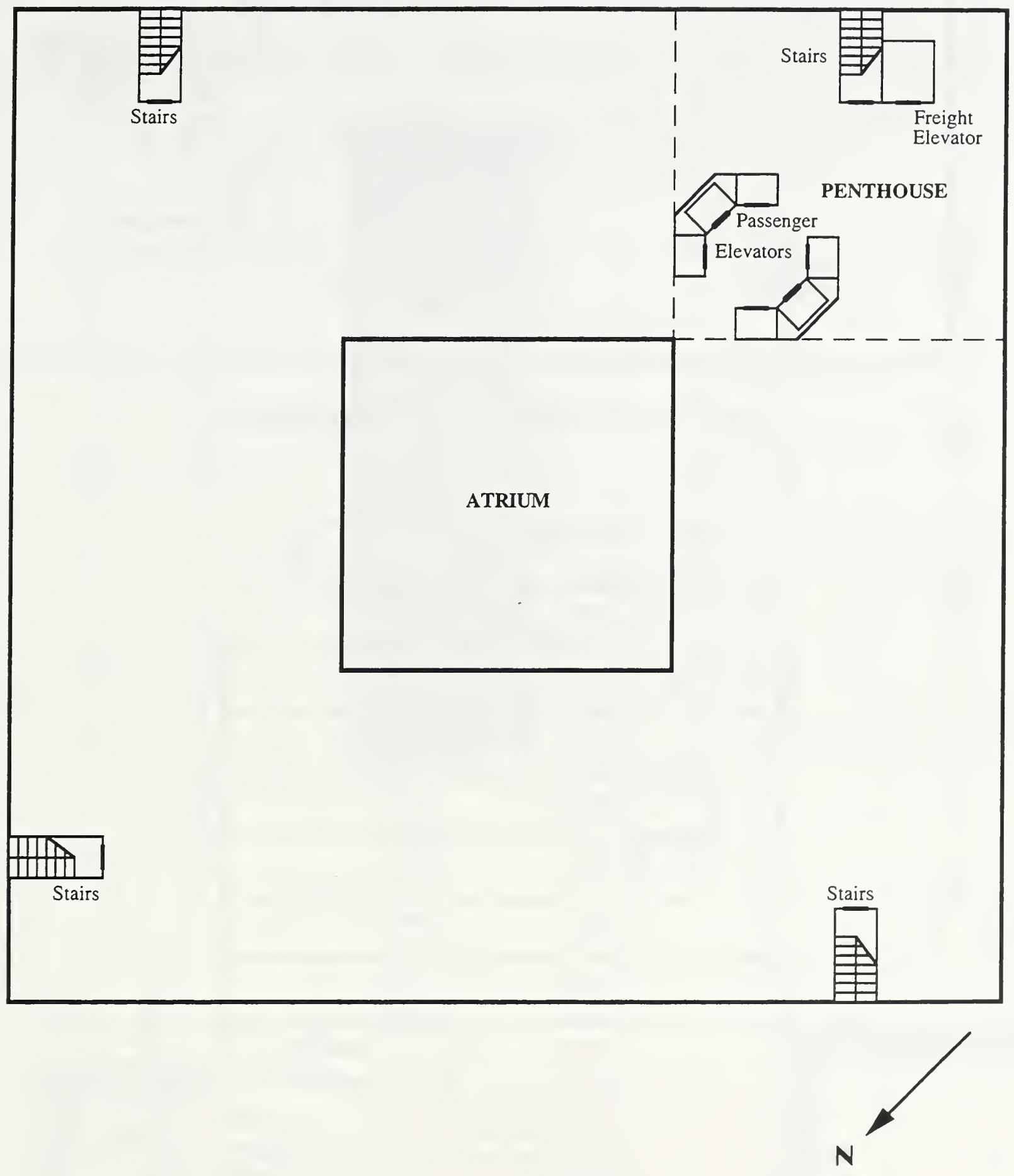

Figure 4 Level-5 Floor Plan of Office Building No. 1 
Freight

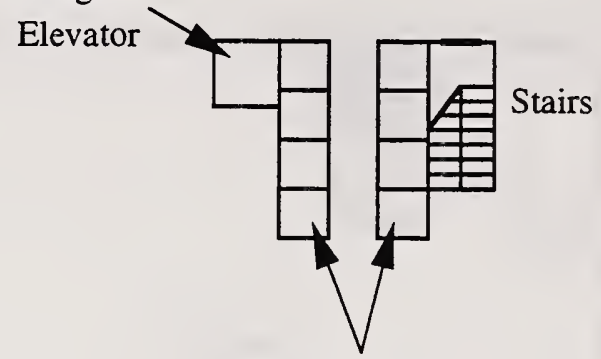

Passenger

Elevators

Figure 5 Typical Floor Plan of Office Building No. 2

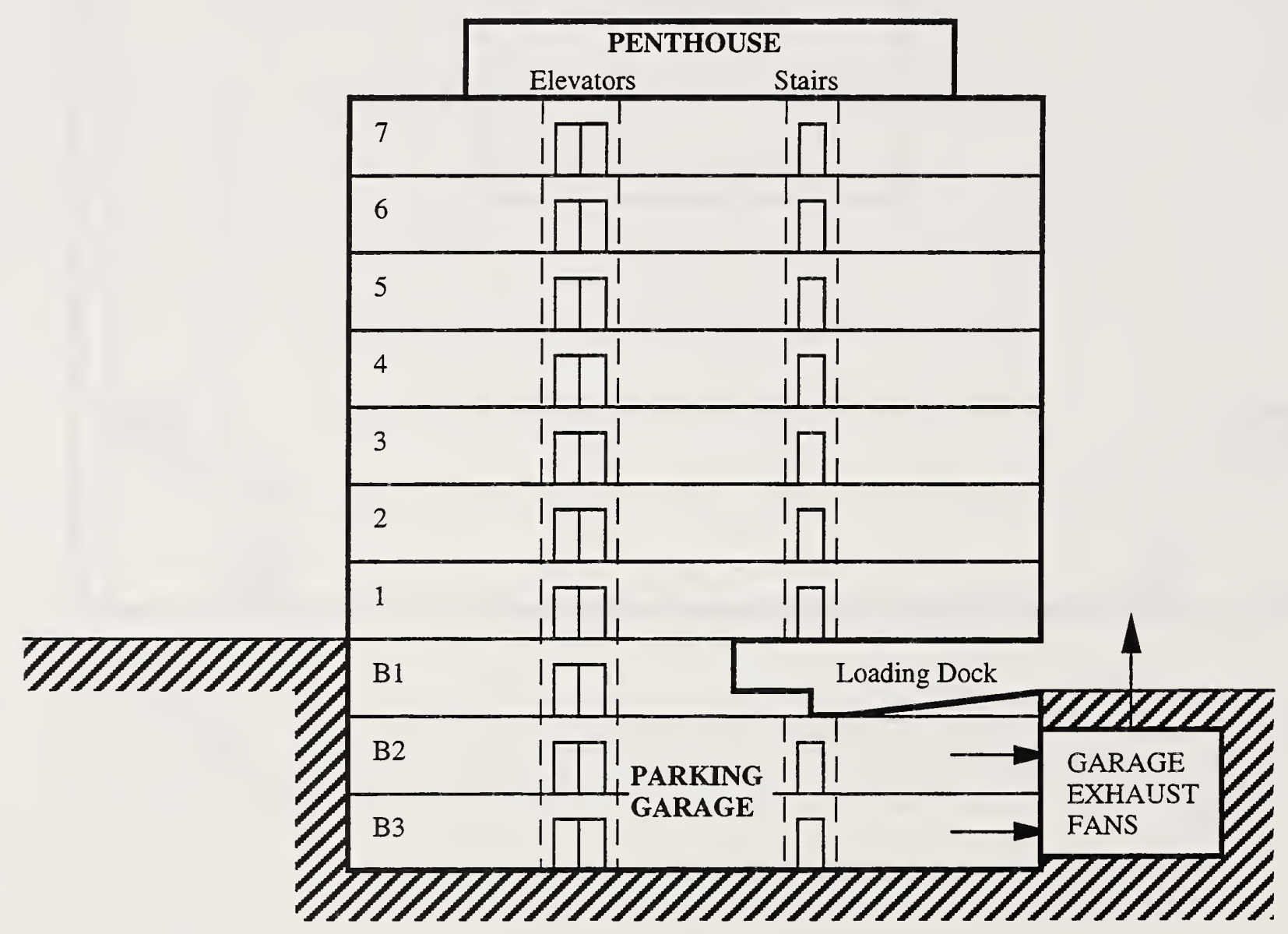

Figure 6 Schematic of Office Building No. 2 


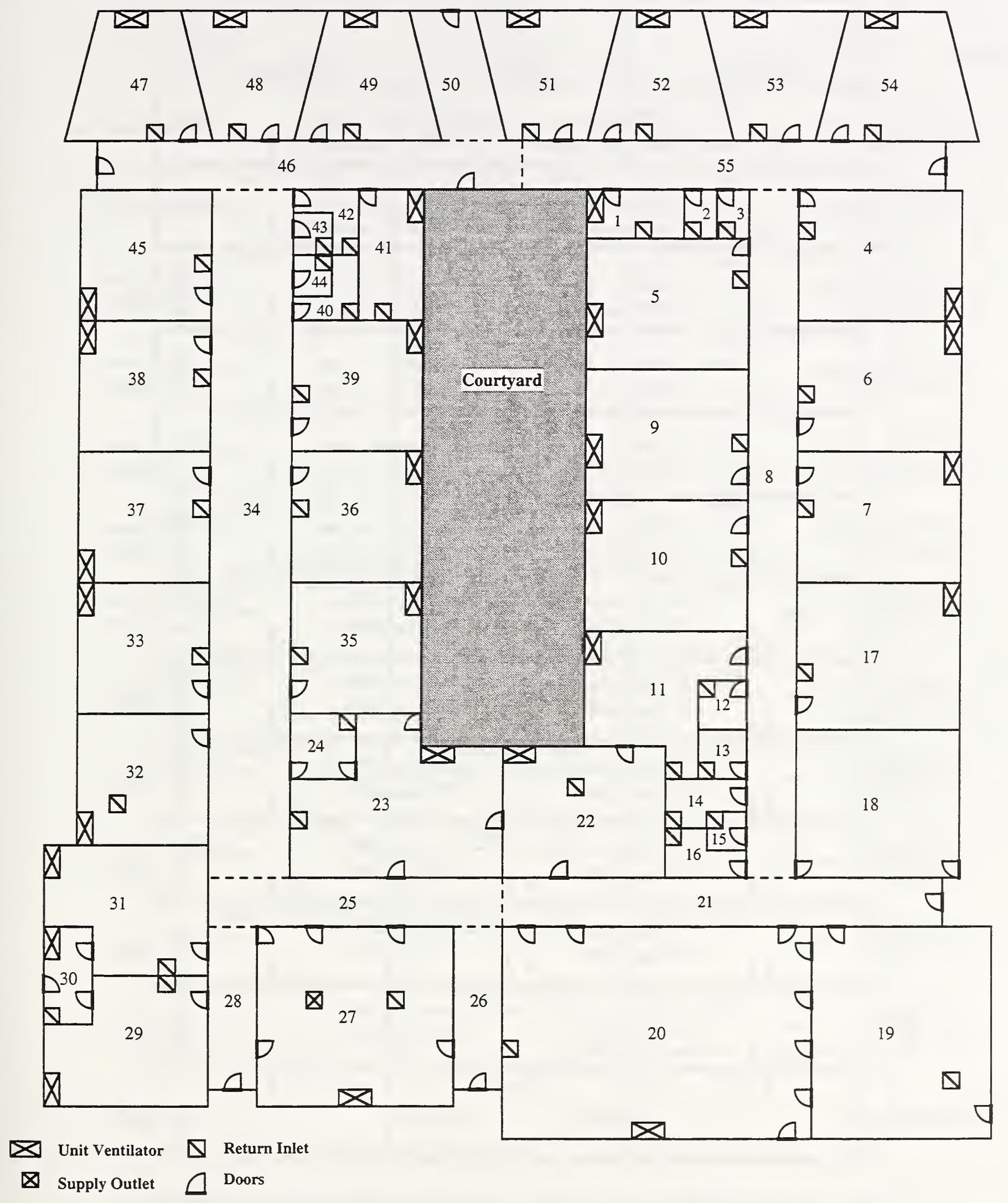

Figure 7 Floor Plan of School Building 


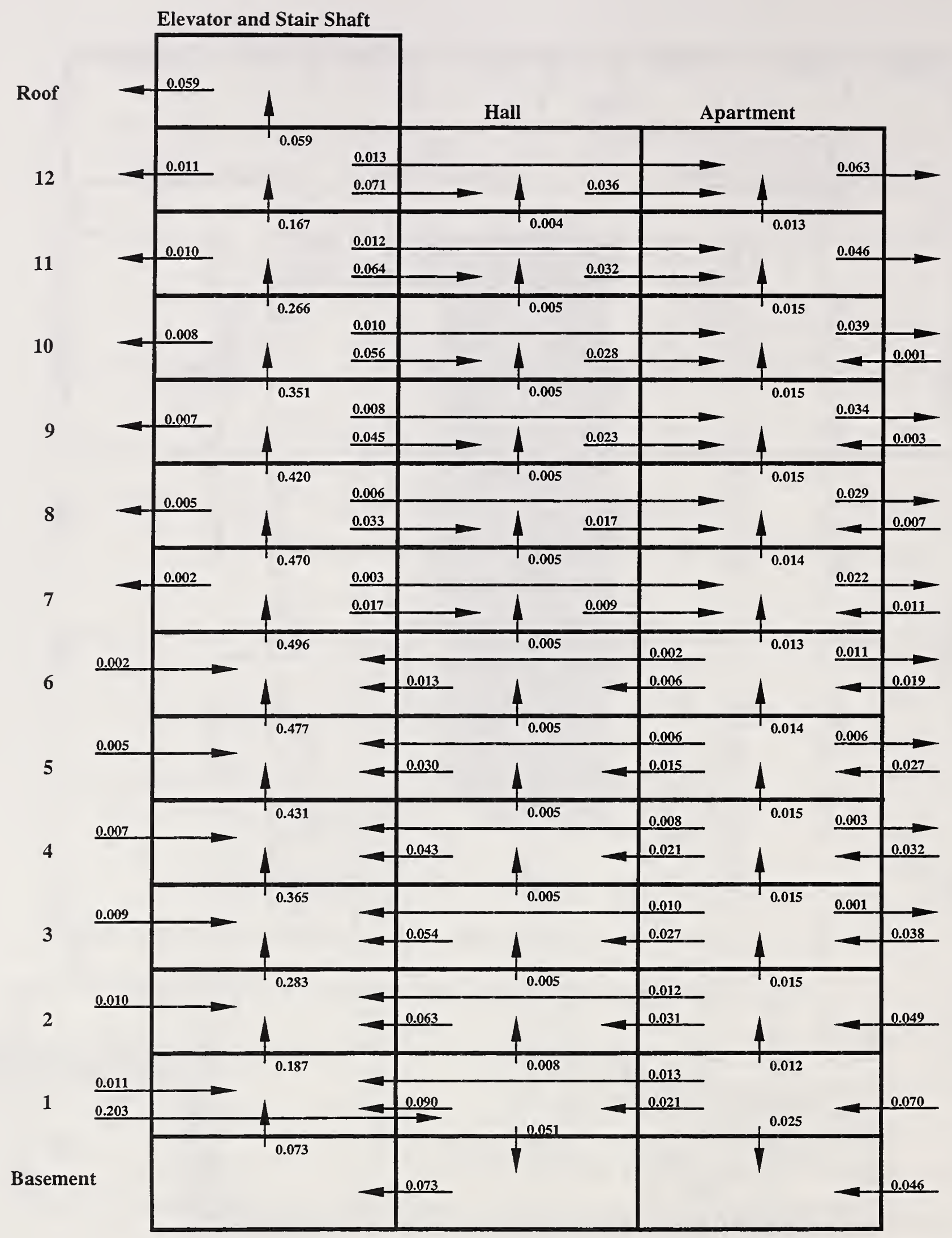

All flows are in $\mathrm{kg} / \mathrm{s}$. The indoor-outdoor temperature difference equals $20^{\circ} \mathrm{C}$ and ambient wind speed equals $0 \mathrm{~m} / \mathrm{s}$.

Figure 8 Airflow Rates in Apartment Building 


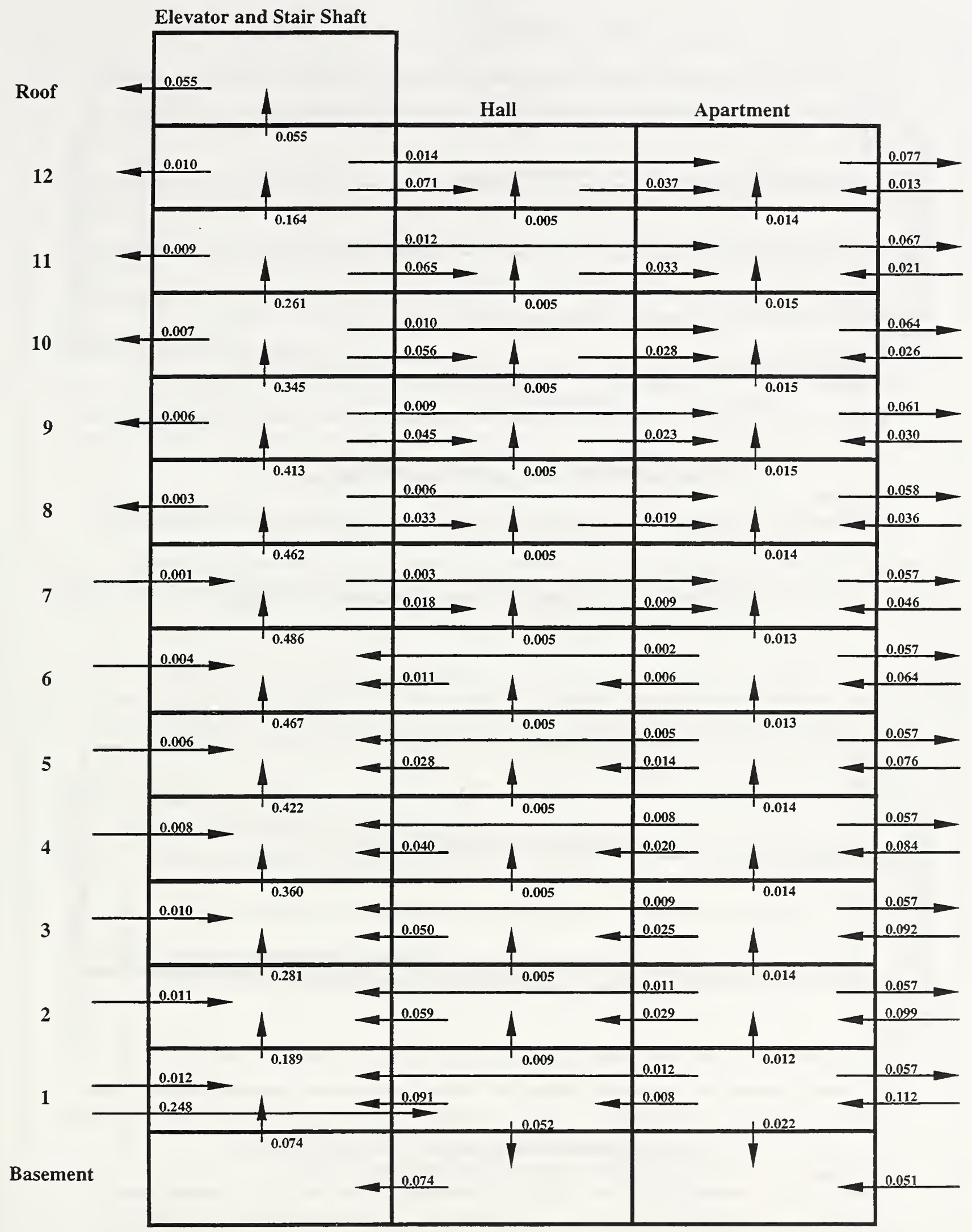

All flows are in $\mathrm{kg} / \mathrm{s}$. The indoor-outdoor temperature difference equals $20^{\circ} \mathrm{C}$ and ambient wind speed equals $0 \mathrm{~m} / \mathrm{s}$.

Figure 9 Airflow Rates in Apartment Building with Exhaust Fans 


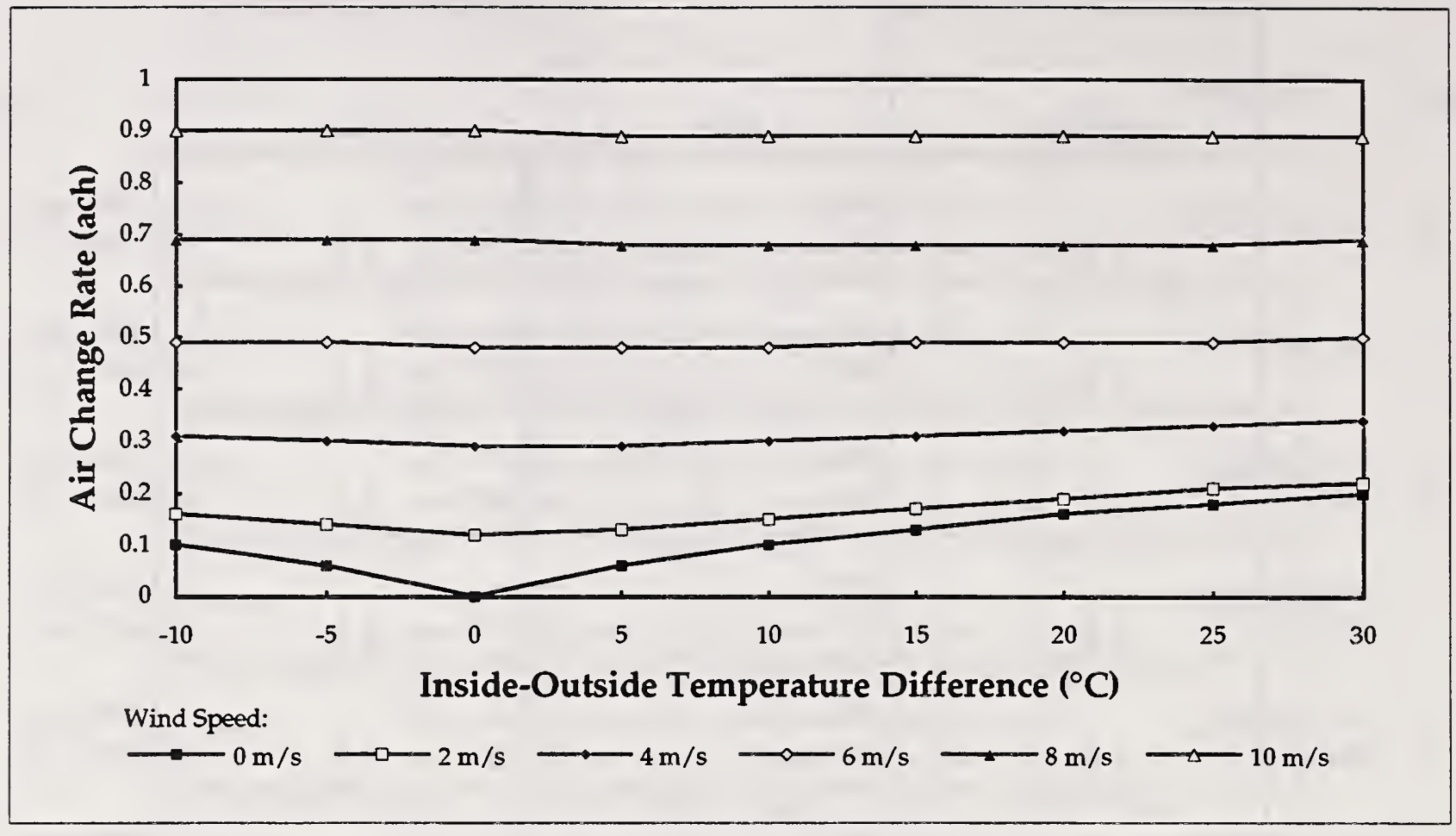

Figure 10 Air Change Rates of Apartment Building

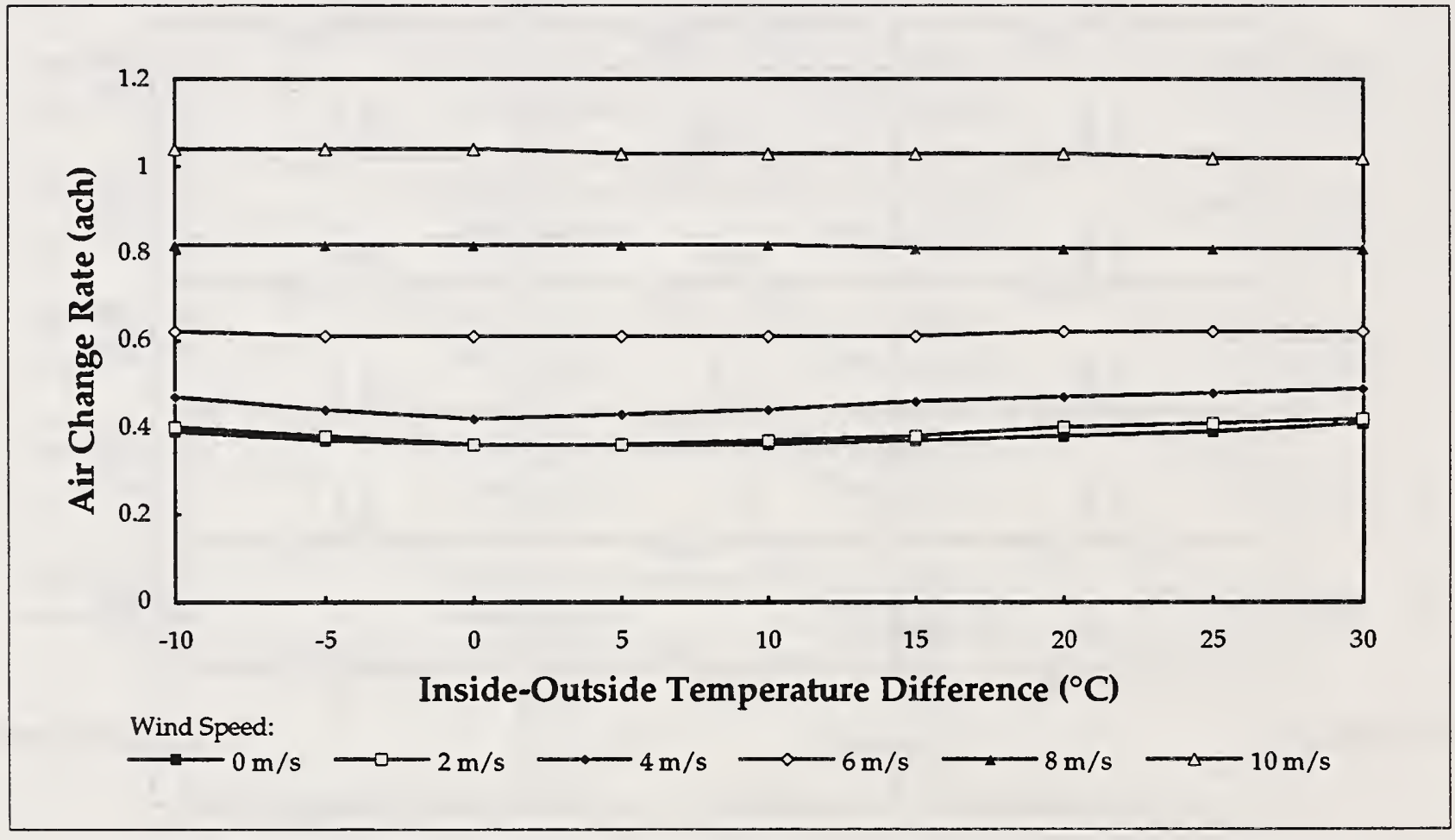

Figure 11 Air Change Rates of Apartment Building with Exhaust Fans Operating 


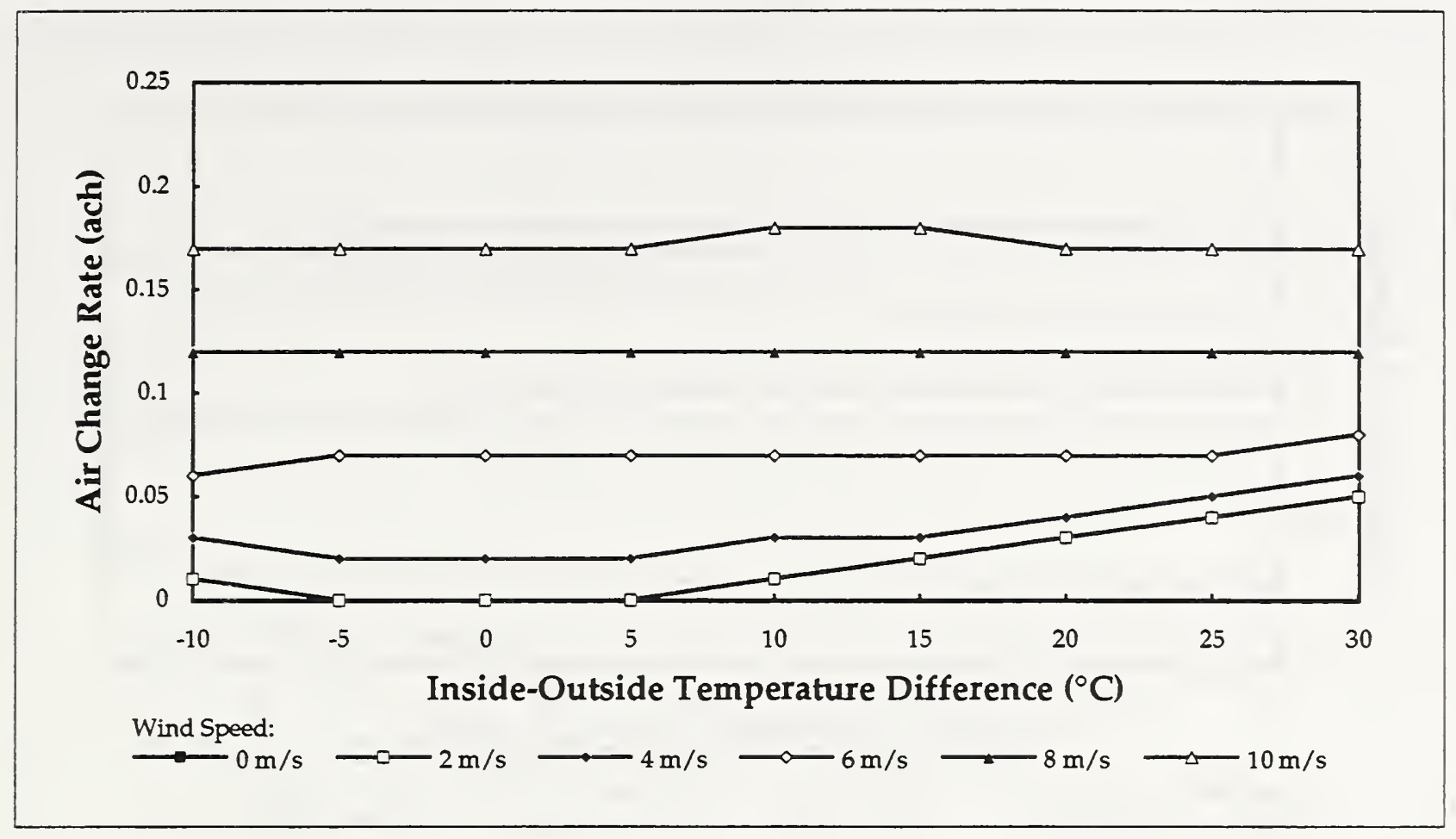

Figure 12 Air Infiltration Rates of Office Building No. 1 with 100\% Outdoor Air Intake

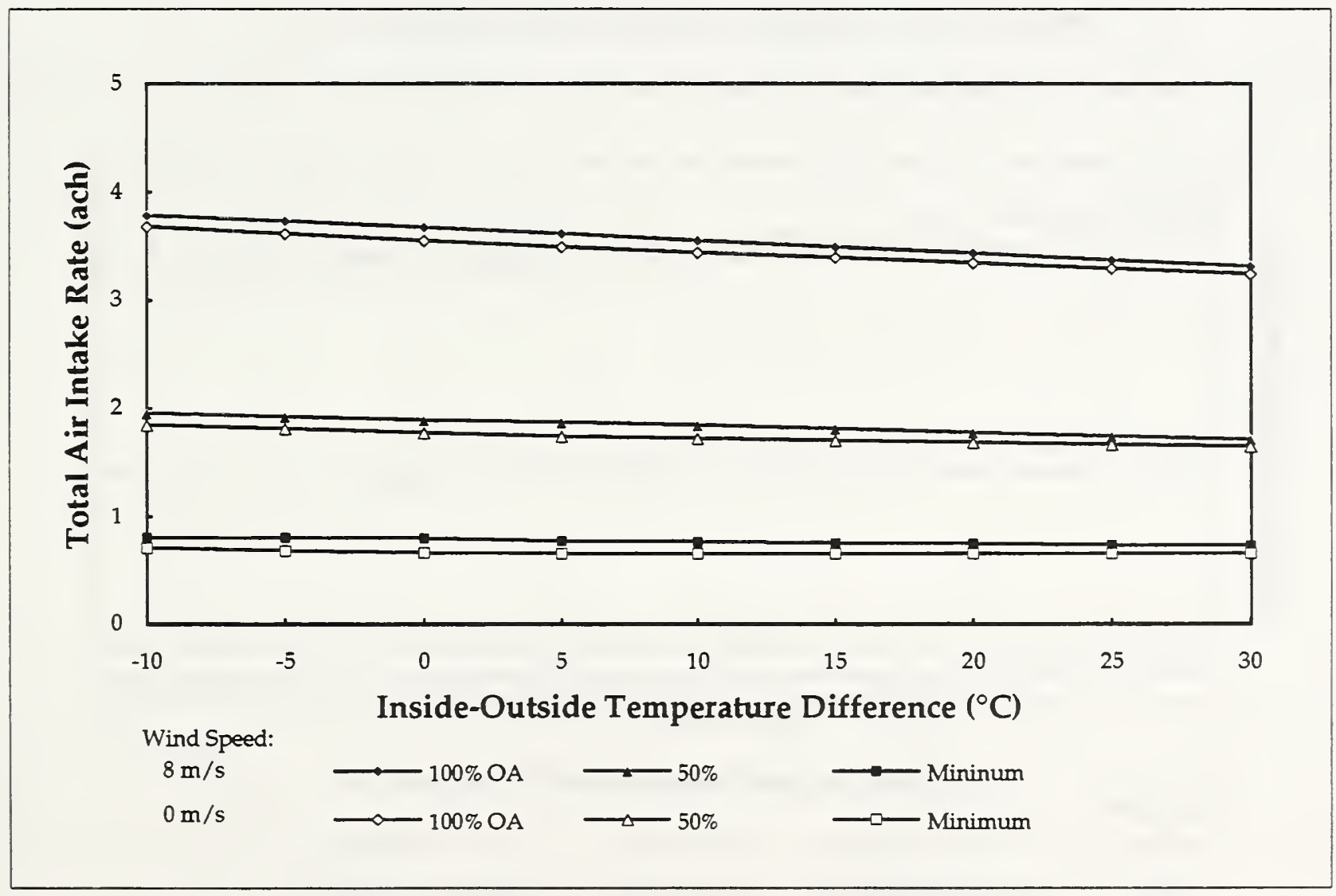

Figure 13 Total Air Intake Rates of Office Building No. 1 


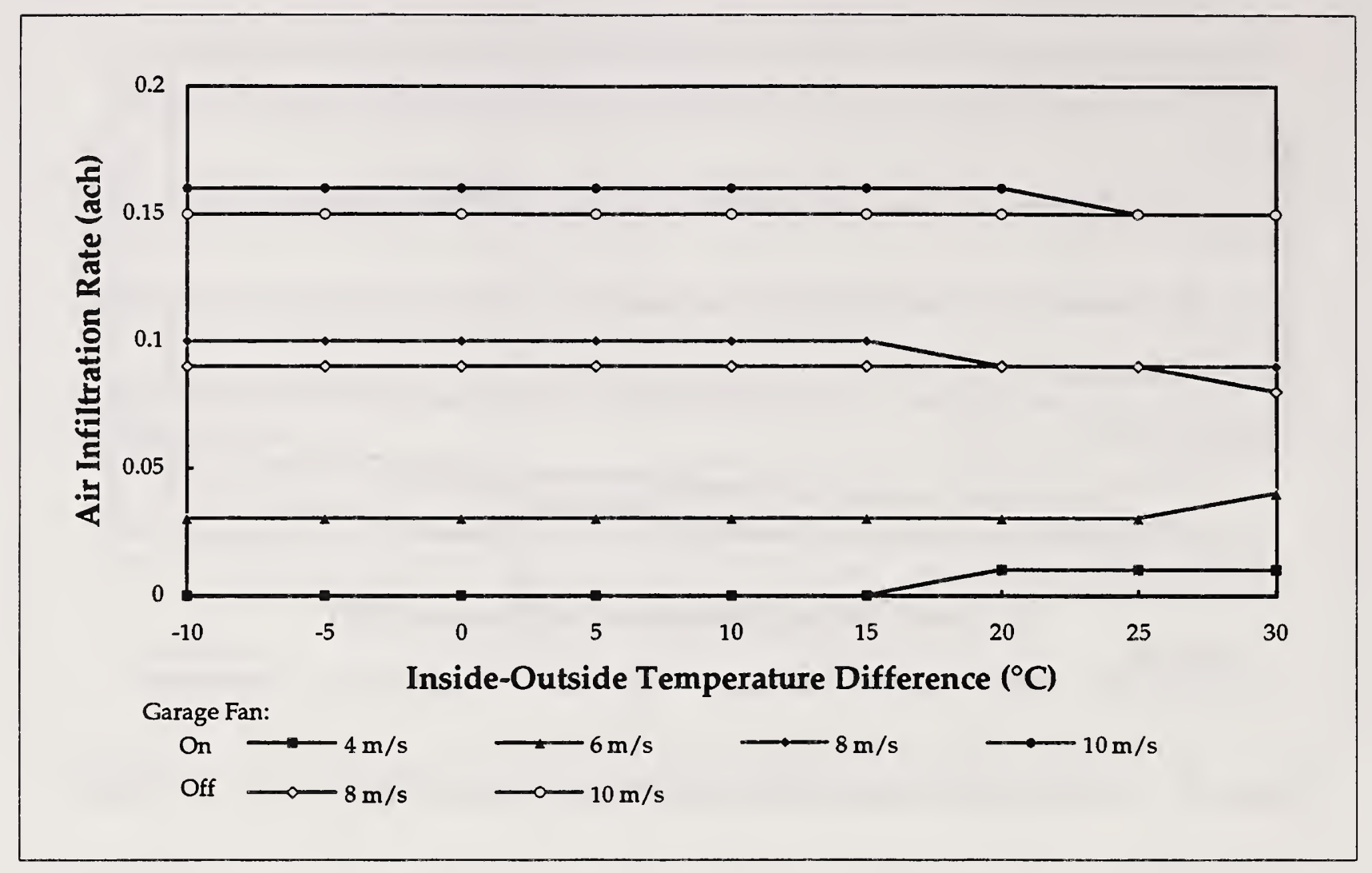

Figure 14 Air Infiltration Rates of Office Building No. 2

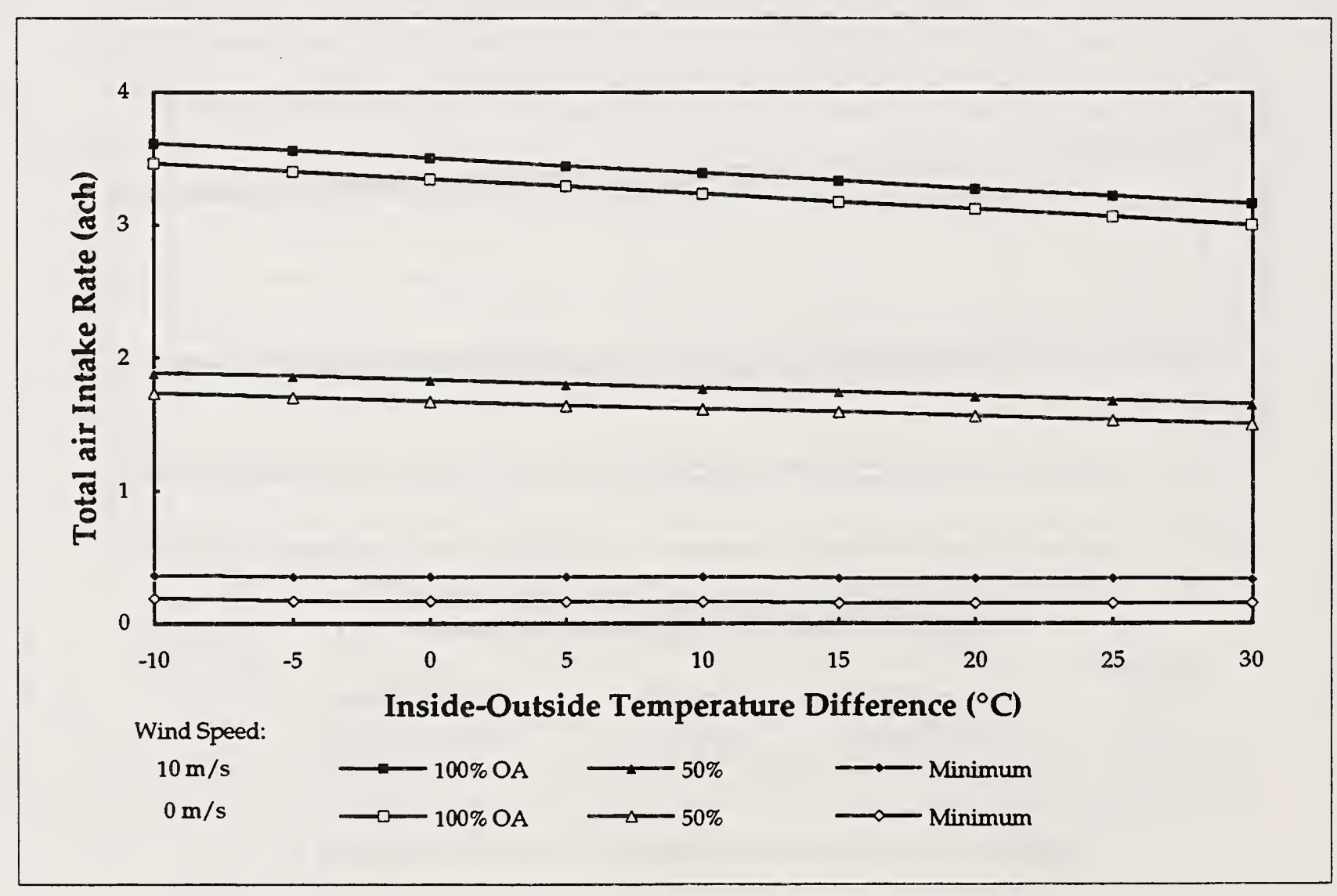

Figure 15 Total Air Intake Rates of Office Building No. 2 


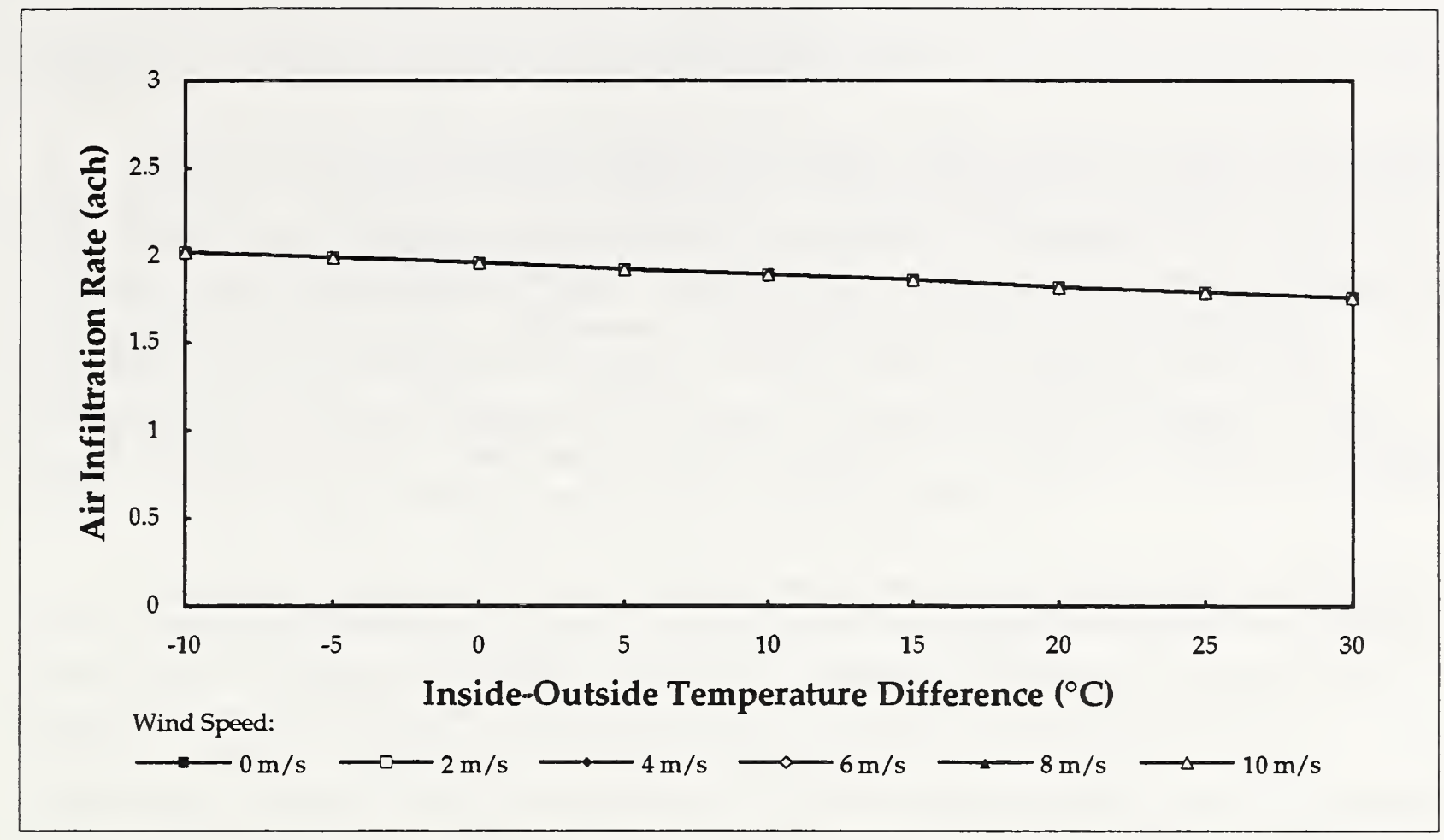

Figure 16 Air Infiltration Rates of School Building

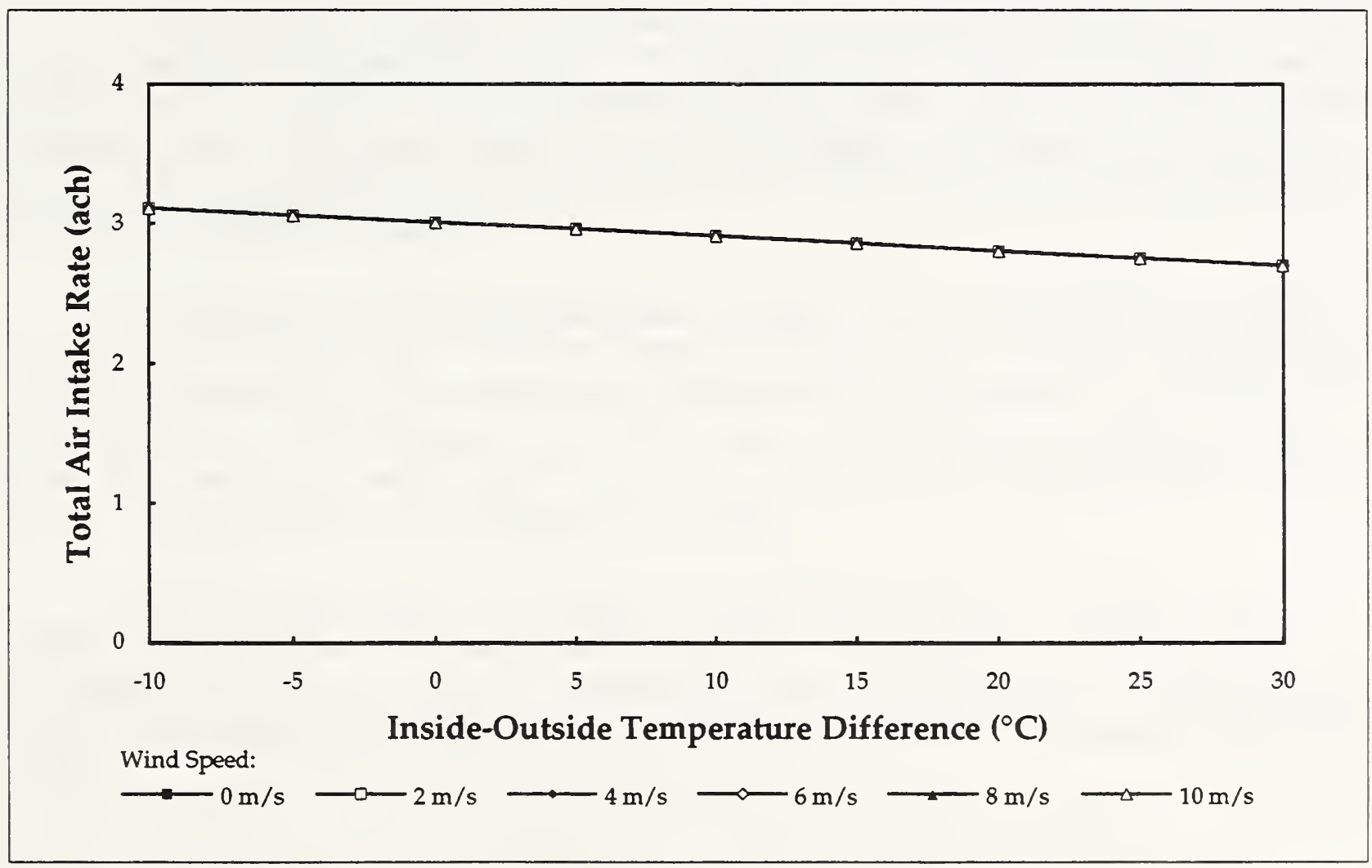

Figure 17 Total Air Intake Rates of School Building 
Appendix A. Building Component Air Leakage Database

Multi-zone airflow modeling requires air leakage values for every significant opening in the exterior envelope and in interior partitions. Determining these air leakage values is difficult since the air leakage of an individual building element depends on its design, installation and deterioration over time. The only way to know the air leakage characteristics of an element is to measure it. However, it is impractical to measure all the leakage characteristics of all openings in a building. In many cases, air leakage values from measurements on similar components can be used in airflow modeling. However, only limited measurements have been made in large buildings. This appendix presents air leakage values relevant to large buildings from the published literature.

The leakage characteristics of a building component can be measured by imposing a series of pressure differences across the component and measuring the airflow rate required to maintain each pressure difference. So-called component pressurization techniques are discussed in ASTM Standards E-283 [A1] and E-783 [A2] for measurements in the laboratory and field, respectively. Whole building pressurization testing involves pressurizing an entire building and measuring the airflow rate required to do so. The results of the these measurements give the leakage characteristics for all the building leakage in combination. Whole building pressurization is described in ASTM Standard E-779 [A3].

Over the years, a number of component and whole building pressurization tests have been conducted in commercial buildings. This appendix is the result of a literature search of leakage data in large public and commercial buildings published after 1970. There is also a significant amount of leakage data on single-family residential buildings, for example in Chapter 23 of the ASHRAE Fundamentals Handbook [A4], but this appendix is limited to data from commercial buildings.

The appendix presents the leakage data in tabular form and organized by building component and building type. The first column in the table is the effective leakage area at a reference pressure of $4 \mathrm{~Pa}$ and a discharge coefficient of 1.0. The next column contains a brief description of the component. The third column states whether the leakage area is based on a component leakage test (C) or is derived from a whole building pressurization test (WB). The last column is the reference for the data.

The air leakage data in the literature is reported in a variety of different forms including leakage areas and leakage coefficients of a variety of reference pressures and discharge coefficients. The $4 \mathrm{~Pa}$ effective leakage areas in the table were converted from the reported form using the forumlas in Chapter 23 of the ASHRAE Fundamentals Handbook [A4]. 
Table A1. Effective Leakage Area (in $\mathrm{cm}^{2} / \mathrm{m}^{2}$ ) of Building Components

ELA at

Component Description

Basis

Reference No.

$4 \mathrm{~Pa}$

Exterior Walls - Office Buildings

3.64 Precast concrete panel

WB

A5

2.74 Precast concrete panel walls retrofitted

WB

A6

with rigid insulation after about 20 years

1.63 Precast concrete panel

WB

A5

1.02 Precast concrete panel walls retrofitted

WB

A6 with all windows and vertical columns recaulked after about 20 years

0.55 Precast concrete panel

WB

A5

1.91 Metal panel

WB

A5

1.08 Metal panel walls retrofitted by replacing

WB

A6

metal panel with a curtain wall cladding

system after about 20 years

1.36 Metal panel

WB

A5

1.36 Metal panel walls retrofitted with all

WB

A6

joints in the curtain wall recaulked

after about 20 years

1.30 Precast concrete panel

WB

A5

1.60 Precast concrete panel walls after

WB

A6

about 20 years

1.87 Precast concrete panel

WB

A5

1.35 Precast concrete panel walls retrofitted

WB

A6

by installing a new roof

0.50 Metal panel

WB 
2.10 Precast concrete panel WB

1.30 Tile veneer, concrete masonry backup WB

$1.90 \quad$ Stone panel

WB

A7

0.60 Brick veneer, concrete masonry backup

WB

2.30 Brick veneer, steel stud backup

WB

1.10 Brick veneer, brick backup

WB

2.90 Precast concrete panel

WB

5.20 Glass and metal curtain wall

WB

4.97 Glass and metal curtain wall

WB

A9

2.53 Precast concrete panel

WB

PEAC panel

WB

1.00 Glass and metal curtain wall

WB

0.53

Precast concrete panel

WB

Exterior Walls - Apartment Buildings

4.50 Brick veneer, concrete masonry backup

C

2.70 Brick veneer, concrete masonry backup

C

3.12

Masonry panel

WB

A12

1.13

Masonry panel

WB 
Exterior Walls - School Buildings

6.7 Brick veneer, concrete masonry backup WB

4.8 Brick veneer, concrete masonry backup

WB

A13

2.9 Brick veneer, concrete masonry backup

WB

Exterior Walls - Supermarkets and Shopping Malls

15.7 Concrete block

WB

A14

9.20

Brick veneer, concrete masonry backup

WB

A14

2.60

Concrete block, steel stud backup

WB

A14

Floors - Office Buildings

0.39 Reinforced concrete

C

A15

0.26 Reinforced concrete

C

A 15

0.22 Reinforced concrete

C

A15

Floors - Apartment Buildings

$0.32 \quad$ Not available

C

$0.26 \quad$ Not available

C

A11

$0.20 \quad$ Not available

C

A11

0.12

Not available

C

Interior Partition Walls - Apartment Buildings

4.30 Gypsum board on stud wall

C

$1.90 \quad$ Gypsum board on stud wall

C

A11

$0.53 \quad$ Gypsum board on stud wall

C 
Elevator Shaft Walls - Office Buildings

7.50 Hollow clay tile block or concrete block C

C A16

3.50 Cast-in-place concrete

C $\quad$ A16

$0.75 \quad$ Cast-in-place concrete

C

A16

Stairwell Walls - Office Buildings

$\begin{array}{llll}1.50 & \text { Cast-in-place concrete } & \text { C } & \text { A16 } \\ 0.46 & \text { Cast-in-place concrete } & \text { C } & \text { A16 } \\ 0.06 & \text { Cast-in-place concrete } & \text { C } & \text { A16 }\end{array}$

Elevator Doors - Office Buildings

$174 \quad 1.07 \mathrm{~m}$ wide $\times 2.13 \mathrm{~m}$ high, with a

C $\quad$ A16 crack width of $6.8 \mathrm{~mm}$

145

$1.07 \mathrm{~m}$ wide $\mathrm{x} 2.13 \mathrm{~m}$ high, with a

C

A16

62 crack width of $5.8 \mathrm{~mm}$

C $\quad$ A16

$1.07 \mathrm{~m}$ wide $\mathrm{x} 2.13 \mathrm{~m}$ high, with a crack width of $5.3 \mathrm{~mm}$ 


\section{REFERENCES}

A1. ASTM. 1991. "Standard Test Method for Determining the Rate of Air Leakage Through Exterior Windows, Curtain Walls, and Doors Under Specified Pressure Differences Across the Specimen," Standard E-283, American Society for Testing and Materials, Philadelphia, PA.

A2. ASTM. 1991. "Standard Test Method for Field Measurement of Air Leakage Through Installed Exterior Windows and Doors," Standard E-783, American Society for Testing and Materials, Philadelphia, PA.

A3. ASTM. 1992. "Standard Test Method for Determining Air Leakage Rate by Fan Pressurization," Standard E-779, American Society for Testing and Materials, Philadelphia, PA.

A4. ASHRAE. 1993. ASHRAE Fundamentals Handbook, American Society of Heating, Refrigerating and Air-Conditioning Engineers, Atlanta, GA.

A5. Tamura, G.T. and C.Y. Shaw. 1976. " Studies on Exterior Wall Air Tightness and Air Infiltration of Tall Buildings," ASHRAE Transactions, Vol. 82, Part 1, 122-134.

A6. Shaw, C.Y., J.T. Reardon and M.S. Cheung. 1993. "Changes in Air Leakage Levels of Six Canadian Office Buildings," ASHRAE Journal, Vol. 35, 34-36.

A7. Persily, A.K. and R.A. Grot. 1985. "The Airtightness of Office Building Envelopes," Proceedings of Thermal Performance of Exterior Envelopes of Buildings III, ASHRAE Special Publication.

A8. Persily, A.K., W.S. Dols, S.J. Nabinger and S. Kirchner. 1991. "Preliminary Results of the Environmental Evaluation of the Federal Records Center in Overland Missouri," NISTIR 4634, National Institute of Standards and Technology, Gaithersburg, MD.

A9. Perera, M.D.A.E.S., R.K. Stephen and R.G. Tull. 1990. "Airtightness Measurements in Two UK Office Buildings," Air Change Rate and Airtightness in Buildings, ASTM STP 1067, M.H. Sherman, Ed., American Society for Testing and Materials, Philadelphia, 211-221.

A10. Shaw, C.Y., D.M. Sander and G.T. Tamura. 1973. "Air Leakage Measurements of the Exterior Walls of Tall Buildings," ASHRAE Transactions, Vol. 79, Part 2, 40-48.

A11. Shaw, C.Y., R.J. Magee and J. Rousseau. 1991. "Overall and Component Airtightness Values of a Five-Story Apartment Building," ASHRAE Transactions, Vol. 97, Part 2, 347-353. 
A12. Shaw, C.Y., S. Gasparetto and J.T. Reardon. 1990. "Methods for Measuring Air Leakage in High-Rise Apartments," Air Change Rate and Airtightness in Buildings, M.H. Sherman Ed., ASTM STP 1067, American Society for Testing and Materials, Philadelphia, 222-230.

A13. Shaw, C.Y. and L. Jones. 1979. "Air Tightness and Air Infiltration of School Buildings," ASHRAE Transactions, Vol. 85, Part 1, 85-95.

A14. Shaw, C.Y. 1981. "Air Tightness: Supermarkets and Shopping Malls," ASHRAE Journal, Vol. 23, 44-46.

A15. Tamura, G.T. and C.Y. Shaw. 1978. "Experimental Studies of Mechanical Venting for Smoke control in Tall Office Buildings," ASHRAE Transactions, Vol. 84, Part 1, 54-71.

A16. Tamura, G.T. and C.Y. Shaw. 1976. "Air Leakage Data for the Design of Elevator and Stair Shaft Pressurization Systems, "ASHRAE Transactions, Vol. 82, Part 2, 179-190. 

Appendix B. Sample Building Documentation File

CONTAM88 building description files (.DSC) are created with the NBSAVIS program and contain all necessary information on the building. However, these DSC files do not provide convenient summaries of the building description. It is generally useful to create a documentation file with a text editor or word processor that summarizes the building description. The following is an example of a building documentation file, APARTEX.DSC.

APARTMENT 12-story; 4 apartments per floor except 1st floor: entrance and 2 apartments with a lobby on 1st floor; basement; 14-story elevator and stairwell; and hallway; roof height $=30.0 \mathrm{~m} ; 87$ building zones; 47 $\mathrm{L} / \mathrm{s}$ exhaust air from each apartment.

The zone names of the apartment building are:

$\begin{array}{llllllll}\# 1 & \text { elevbase } & \# 29 & \text { hall1st } & \# 53 & \text { Apt 1B } & \# 76 & \text { Apt 2D } \\ \# 2 & \text { elev1st } & \# 30 & \text { hall2nd } & \# 54 & \text { Apt 2B } & \# 77 & \text { Apt 3D } \\ \# 3 & \text { elev2nd } & \# 31 & \text { hall3rd } & \# 55 & \text { Apt 3B } & \# 78 & \text { Apt 4D } \\ \# 4 & \text { elev3rd } & \# 32 & \text { hall4th } & \# 56 & \text { Apt 4B } & \# 79 & \text { Apt 5D } \\ \# 5 & \text { elev4th } & \# 33 & \text { hall5th } & \# 57 & \text { Apt 5B } & \# 80 & \text { Apt 6D } \\ \# 6 & \text { elev5th } & \# 34 & \text { hall6th } & \# 58 & \text { Apt 6B } & \# 81 & \text { Apt 7D } \\ \# 7 & \text { elev6th } & \# 35 & \text { hall7th } & \# 59 & \text { Apt 7B } & \# 82 & \text { Apt 8D } \\ \# 8 & \text { elev7th } & \# 36 & \text { hall8th } & \# 60 & \text { Apt 8B } & \# 83 & \text { Apt 9D } \\ \# 9 & \text { elev8th } & \# 37 & \text { hall9th } & \# 61 & \text { Apt 9B } & \# 84 & \text { Apt 10D } \\ \# 10 & \text { elev9th } & \# 38 & \text { hall10th } & \# 62 & \text { Apt 10B } & \# 85 & \text { Apt 11D } \\ \# 11 & \text { elev10th } & \# 39 & \text { hall11th } & \# 63 & \text { Apt 11B } & \# 86 & \text { Apt 12D } \\ \# 12 & \text { elev11th } & \# 40 & \text { hall12th } & \# 64 & \text { Apt 12B } & \# 87 & \text { basement } \\ \# 13 & \text { elev12th } & & & & & & \\ \# 14 & \text { elevroof } & & & & & & \\ & & & & & & \\ \# 15 & \text { stairbase } & \# 41 & \text { Apt 1A } & \# 65 & \text { Apt 2C } & & \\ \# 16 & \text { stair1st } & \# 42 & \text { Apt 2A } & \# 66 & \text { Apt 3C } & & \\ \# 17 & \text { stair2nd } & \# 43 & \text { Apt 3A } & \# 67 & \text { Apt 4C } & & \\ \# 18 & \text { stair3rd } & \# 44 & \text { Apt 4A } & \# 68 & \text { Apt 5C } & & \\ \# 19 & \text { stair4th } & \# 45 & \text { Apt 5A } & \# 69 & \text { Apt 6C } & & \\ \# 20 & \text { stair5th } & \# 46 & \text { Apt 6A } & \# 70 & \text { Apt 7C } & & \\ \# 21 & \text { stair6th } & \# 47 & \text { Apt 7A } & \# 71 & \text { Apt 8C } & & \\ \# 22 & \text { stair7th } & \# 48 & \text { Apt 8A } & \# 72 & \text { Apt 9C } & & \\ \# 23 & \text { stair8th } & \# 49 & \text { Apt 9A } & \# 73 & \text { Apt 10C } & & \\ \# 24 & \text { stair9th } & \# 50 & \text { Apt 10A } & \# 74 & \text { Apt 11C } & & \\ \# 25 & \text { stair10th } & \# 51 & \text { Apt 11A } & \# 75 & \text { Apt 12C } & & \\ \# 26 & \text { stair11th } & \# 52 & \text { Apt 12A } & & & & \\ \# 27 & \text { stair12th } & & & & & & \\ \# 28 & \text { stairroof } & & & & & & \\ & & & & & & & \end{array}$


The leakage areas of various building components are as follows:

Exterior wall types

1 apartment

LA(Leakage Area $)=3.0 \mathrm{~cm}^{2} / \mathrm{m}^{2}$

2 floor $\mathrm{x}($ Pressure Exponent $)=0.60$

$\mathrm{LA}=0.017 \mathrm{~cm}^{2} / \mathrm{m}^{2}, \mathrm{x}=1.0$

Exterior door types

1 main

$\mathrm{LA}=58 \mathrm{~cm}^{2}, 2.13(\mathrm{H}) \times 3.90 \mathrm{~m}, \mathrm{~A}=3.9 \mathrm{~m}^{2}$

2 elevator

$\mathrm{LA}=29 \mathrm{~cm}^{2}, 2.13(\mathrm{H}) \times 0.91 \mathrm{~m}$ (on roof), $\mathrm{A}=1.95 \mathrm{~m}^{2}$

3 stairway

$\mathrm{LA}=29 \mathrm{~cm}^{2}, 2.13(\mathrm{H}) \times 0.91 \mathrm{~m}$ (on roof), $\mathrm{A}=1.95 \cdot \mathrm{m}^{2}$

Window types

1 exterior $\quad \mathrm{LA}=7.5 \mathrm{~cm}^{2}, 0.75 \mathrm{~m}$ above wall base, $\mathrm{H}=1.5 \mathrm{~m}, \mathrm{~A}=1.5 \mathrm{~m}^{2}$

2 basement $\mathrm{LA}=1.35 \mathrm{~cm}^{2}, 0.1 \mathrm{~m}$ above wall base, $\mathrm{H}=0.3 \mathrm{~m}, \mathrm{~A}=0.27 \mathrm{~m}^{2}$

Interior wall types

$\begin{array}{lll}1 & \text { apartment } & \mathrm{LA}=2.0 \mathrm{~cm}^{2} / \mathrm{m}^{2} \\ 2 & \text { elevator } & \mathrm{LA}=5.0 \mathrm{~cm}^{2} / \mathrm{m}^{2} \\ 3 & \text { stairway } & \mathrm{LA}=5.0 \mathrm{~cm}^{2} / \mathrm{m}^{2} \\ 4 & \text { floor } & \mathrm{LA}=0.5 \mathrm{~cm}^{2} / \mathrm{m}^{2} \\ 5 & \text { shaft } & \mathrm{LA}=10000 \mathrm{~cm}^{2} / \mathrm{m}^{2}\end{array}$

Interior door types

1 apartment $\mathrm{LA}=75 \mathrm{~cm}^{2}, 2.13(\mathrm{H}) \times 0.91 \mathrm{~m}, \mathrm{~A}=1.95 \mathrm{~m}^{2}$

2 elevator $L A=150 \mathrm{~cm}^{2}, 2.13(\mathrm{H}) \times 1.41 \mathrm{~m}, \mathrm{~A}=3.0 \mathrm{~m}^{2}$

3 stairway $\mathrm{LA}=150 \mathrm{~cm}^{2},{ }^{2} .13(\mathrm{H}) \times 1.41 \mathrm{~m}, \mathrm{~A}=3.0 \mathrm{~m}^{2}$

Vent/Miscellaneous opening types

1 shortlow $\mathrm{LA}=25 \mathrm{~cm}^{2}, \mathrm{Hfl}=0.0 \mathrm{~m}, \mathrm{x}=0.6$,

$\mathrm{OA}($ Opening Area $)=2.50 \mathrm{E}-03 \mathrm{~m}^{2}$

2 shorthigh $\mathrm{LA}=25 \mathrm{~cm}^{2}, \mathrm{Hfl}=2.5 \mathrm{~m}, \mathrm{x}=0.6$,

$\mathrm{OA}=2.50 \mathrm{E}-03 \mathrm{~m}^{2}$

3 longlow $\mathrm{LA}=37.5 \mathrm{~cm}^{2}, \mathrm{Hfl}=0.0 \mathrm{~m}, \mathrm{x}=0.6$,

$\mathrm{OA}=3.75 \mathrm{E}-03 \mathrm{~m}^{2}$

4 longhigh $\mathrm{LA}=37.5 \mathrm{~cm}^{2}, \mathrm{Hfl}=2.5 \mathrm{~m}, \mathrm{x}=0.6$,

$\mathrm{OA}=3.75 \mathrm{E}-03 \mathrm{~m}^{2}$

Fan types

1 exhaust $\quad 2.50 \mathrm{~m}$ above floor, with a fan capacity of

$0.047 \mathrm{~m}^{3} / \mathrm{s}$ 
The floor area, height, the height measured above the reference plane, and descriptions of surrounding building components of each zone are as follows:

Elevbase: $\mathrm{A}=5 \mathrm{~m}^{2}, \mathrm{H}=2.5 \mathrm{~m}, \mathrm{Href}=-2.5 \mathrm{~m}, 23 \mathrm{C}$

Elevfloor: $\mathrm{A}=5 \mathrm{~m}^{2}, \mathrm{H}=2.5 \mathrm{~m}$, Href $=0 \mathrm{~m}, 23 \mathrm{C}$

Exterior walls

1 Type 1 apartment, $\mathrm{W}=2.5 \mathrm{~m}, 0$ deg, vert, $\mathrm{H}=2.5 \mathrm{~m} \mathrm{Hfl}=0 \mathrm{~m}$ Interior walls

1 Type 5 shaft, $\mathrm{W}=2.5 \mathrm{~m}$, Adj zone elev-floor-below (from \#1 elevbase), $\mathrm{H}=2.0 \mathrm{~m}, \mathrm{Hfl}=0 \mathrm{~m}$

Elevroof: $\mathrm{A}=5 \mathrm{~m}^{2}, \mathrm{H}=2.5 \mathrm{~m}, \mathrm{Href}=30 \mathrm{~m}, 23 \mathrm{C}$

Exterior walls

1 Type 1 apartment, $\mathrm{W}=2.5 \mathrm{~m}, 0$ deg, vert, $\mathrm{H}=2.5 \mathrm{~m}, \mathrm{Hfl}=0 \mathrm{~m}$

2 Type $1, \mathrm{~W}=2.0 \mathrm{~m}, 90 \mathrm{deg}$, vert, $\mathrm{H}=2.5 \mathrm{~m}, \mathrm{Hfl}=0 \mathrm{~m}$

3 Type $1, \mathrm{~W}=2.5 \mathrm{~m}, 180 \mathrm{deg}$, vert, $\mathrm{H}=2.5 \mathrm{~m}, \mathrm{Hfl}=0 \mathrm{~m}$ 1 Ext door (Type 2 elevator)

4 Type $1, \mathrm{~W}=2.0 \mathrm{~m}, 270 \mathrm{deg}$, vert, $\mathrm{H}=2.5 \mathrm{~m}, \mathrm{Hfl}=0 \mathrm{~m}$ Interior walls

1 Type 5 shaft, $\mathrm{W}=2.5 \mathrm{~m}$, Adj zone \#13 elev12th, $\mathrm{H}=2.0 \mathrm{~m}, \mathrm{Hfl}=0 \mathrm{~m}$

Stairbase: $\mathrm{A}=5 \mathrm{~m}^{2}, \mathrm{H}=2.5 \mathrm{~m}, \mathrm{Href}=-2.5 \mathrm{~m}, 23 \mathrm{C}$

Stairfloor: $\mathrm{A}=5 \mathrm{~m}^{2}, \mathrm{H}=2.5 \mathrm{~m}$, Href $=0 \mathrm{~m}, 23 \mathrm{C}$

Exterior walls

1 Type 1 apartment, $\mathrm{W}=2.5 \mathrm{~m}, 180 \mathrm{deg}$, vert, $\mathrm{H}=2.5 \mathrm{~m}, \mathrm{Hfl}=0 \mathrm{~m}$ Interior walls

1 Type 5 shaft, $\mathrm{W}=2.5 \mathrm{~m}$, Adj zone stair-floor-below $\mathrm{H}=2.0 \mathrm{~m}, \mathrm{Hfl}=0 \mathrm{~m}$

Stairroof: $A=5 \mathrm{~m}^{2}, \mathrm{H}=2.5 \mathrm{~m}, \mathrm{Href}=30 \mathrm{~m}, 23 \mathrm{C}$

Exterior walls

1 Type 1 apartment, $\mathrm{W}=2.5 \mathrm{~m}, 0$ deg, vert, $\mathrm{H}=2.5 \mathrm{~m}, \mathrm{Hfl}=0 \mathrm{~m}$ 1 Ext door (Type 3 stair)

2 Type $1, \mathrm{~W}=2.0 \mathrm{~m}, 90 \mathrm{deg}$, vert, $\mathrm{H}=2.5 \mathrm{~m}, \mathrm{Hfl}=0 \mathrm{~m}$

3 Type $1, \mathrm{~W}=2.5 \mathrm{~m}, 180 \mathrm{deg}$, vert, $\mathrm{H}=2.5 \mathrm{~m}, \mathrm{Hfl}=0 \mathrm{~m}$

4 Type $1, \mathrm{~W}=2.0 \mathrm{~m}, 270 \mathrm{deg}$, vert, $\mathrm{H}=2.5 \mathrm{~m}, \mathrm{Hfl}=0 \mathrm{~m}$

Interior walls

1 Type 5 shaft, $\mathrm{W}=2.5 \mathrm{~m}$, Adj zone \#27 stair 12 th, $\mathrm{H}=2.0 \mathrm{~m}, \mathrm{Hfl}=0 \mathrm{~m}$ 
First floor hall: $A=365 \mathrm{~m}^{2}, \mathrm{H}=2.5 \mathrm{~m}, \mathrm{Href}=0 \mathrm{~m}, 23 \mathrm{C}$

Exterior walls

1 Type 1 apartment, $\mathrm{W}=10 \mathrm{~m}, 0 \mathrm{deg}$, vert, $\mathrm{H}=2.5 \mathrm{~m}, \mathrm{Hfl}=0 \mathrm{~m}$, 3 windows (Type 1 exterior),

2 Vents (Type 1 shortlow; Type 2 shorthigh)

2 Type 1 apartment, $\mathrm{W}=10 \mathrm{~m}, 180 \mathrm{deg}$, vert, $\mathrm{H}=2.5 \mathrm{~m}, \mathrm{Hfl}=0 \mathrm{~m}$, 3 windows (Type 1 exterior),

2 Vents (Type 1 shortlow; Type 2 shorthigh)

3 Type 1 apartment, $\mathrm{W}=30 \mathrm{~m}, 270 \mathrm{deg}$, vert, $\mathrm{H}=2.5 \mathrm{~m}, \mathrm{Hfl}=0 \mathrm{~m}$, 8 windows (Type 1 exterior),

4 Vents (Type 3 longlow; Type 4 longhigh),

1 Ext door (Type 1 main)

Interior walls

1 Type 2 elev, $\mathrm{W}=2.5 \mathrm{~m}$, Adj zone $\# 2$ elev1st, $\mathrm{H}=2.5 \mathrm{~m}, \mathrm{Hfl}=0 \mathrm{~m}$ 1 Int door (Type 2 elevator)

2 Type 3 stair, $\mathrm{W}=2.5 \mathrm{~m}$, Adj zone \#16 stair $1 \mathrm{st}, \mathrm{H}=2.5 \mathrm{~m}, \mathrm{Hfl}=0 \mathrm{~m}$ 1 Int door (Type 3 stair)

3 Type 3 stair, $\mathrm{W}=2.0 \mathrm{~m}$, Adj zone $\# 16$ stair $1 \mathrm{st}, \mathrm{H}=2.5 \mathrm{~m}, \mathrm{Hfl}=0 \mathrm{~m}$

4 Type 2 elev, $\mathrm{W}=2.0 \mathrm{~m}$, Adj zone \#2 elev $1 \mathrm{st}, \mathrm{H}=2.5 \mathrm{~m}, \mathrm{Hfl}=0 \mathrm{~m}$

All other floor halls: $\mathrm{A}=65 \mathrm{~m}^{2}, \mathrm{H}=2.5 \mathrm{~m}, \mathrm{Href}=2.5^{*}($ Floor- 1$) \mathrm{m}, 23 \mathrm{C}$

Interior walls

1 Type 2 elev, $\mathrm{W}=2.5 \mathrm{~m}$, Adj zone elevnth (from \#3 elev2nd), $\mathrm{H}=2.5 \mathrm{~m}, \mathrm{Hfl}=0 \mathrm{~m}$ 1 Int door (Type 2 elevator)

2 Type 3 stair, $\mathrm{W}=2.5 \mathrm{~m}$, Adj zone stairnth (from \#17 stair2nd), $\mathrm{H}=2.5 \mathrm{~m}$, $\mathrm{Hfl}=0 \mathrm{~m}, 1$ Int door (Type 3 stair)

3 Type 4 floor, $\mathrm{W}=26 \mathrm{~m}$, Adj zone hall-floor-below (from $\# 29$ hall1st), $\mathrm{H}=2.5 \mathrm{~m}$, $\mathrm{Hfl}=0 \mathrm{~m}$

First floor Apt 1A (northeast corner): $A=150 \mathrm{~m}^{2}, \mathrm{H}=2.5 \mathrm{~m}, \mathrm{Href}=0 \mathrm{~m}, 23 \mathrm{C}$

Exterior walls

1 Type 1 apartment, $\mathrm{W}=10 \mathrm{~m}, 0 \mathrm{deg}$, vert, $\mathrm{H}=2.5 \mathrm{~m}, \mathrm{Hfl}=0 \mathrm{~m}$,

3 windows (Type 1 exterior)

2 Vents (Type 1 shortlow; Type 2 shorthigh)

1 Exh fan

2 Type 1 apartment, $\mathrm{W}=15 \mathrm{~m}, 90 \mathrm{deg}$, vert, $\mathrm{H}=2.5 \mathrm{~m}, \mathrm{Hfl}=0 \mathrm{~m}$, 4 windows (Type 1 exterior)

2 Vents (Type 3 longlow; Type 4 longhigh)

Interior walls

1 Type 2 elevator, $\mathrm{W}=2.0 \mathrm{~m}$, Adj zone $\# 2$ elev1st, $\mathrm{H}=2.5 \mathrm{~m}, \mathrm{Hfl}=0 \mathrm{~m}$

2 Type 1 apartment, $\mathrm{W}=13 \mathrm{~m}$, Adj zone $\# 29$ hall1 st, $\mathrm{H}=2.5 \mathrm{~m}, \mathrm{Hfl}=0 \mathrm{~m}$ 1 Int door (Type 1 apartment) 
All other floor Apt A (northeast corner): $A=150 \mathrm{~m}^{2}, \mathrm{H}=2.5 \mathrm{~m}, \mathrm{Href}=2.5^{*}($ Floor-1) $\mathrm{m}$, $23 \mathrm{C}$

Exterior walls

1 Type 1 apartment, $\mathrm{W}=10 \mathrm{~m}, 0 \mathrm{deg}$, vert, $\mathrm{H}=2.5 \mathrm{~m}, \mathrm{Hfl}=0 \mathrm{~m}$, 3 windows (Type 1 exterior)

2 Vents (Type 1 shortlow; Type 2 shorthigh)

1 Exh fan

2 Type 1 apartment, $\mathrm{W}=15 \mathrm{~m}, 90 \mathrm{deg}$, vert, $\mathrm{H}=2.5 \mathrm{~m}, \mathrm{Hfl}=0 \mathrm{~m}$, 4 windows (Type 1 exterior)

Interior walls

2 Vents (Type 3 longlow; Type 4 longhigh)

1 Type 2 elev, $\mathrm{W}=2.0 \mathrm{~m}$, Adj zone elevnth (from \#3 elev2nd), $\mathrm{H}=2.5 \mathrm{~m}, \mathrm{Hfl}=0 \mathrm{~m}$

2 Type 1 apartment, $W=13 \mathrm{~m}$, Adj zone hallnth (from \#30 hall2nd), $\mathrm{H}=2.5 \mathrm{~m}$, $\mathrm{Hfl}=0 \mathrm{~m}$

1 Int door (Type 1 apartment)

3 Type 4 floor, $\mathrm{W}=10 \mathrm{~m}$, Adj zone apartment below (from \#41 Apt $1 \mathrm{~A}$ ), $\mathrm{H}=15 \mathrm{~m}$, $\mathrm{Hfl}=0 \mathrm{~m}$

First floor Apt 1B (southeast corner): $A=150 \mathrm{~m}^{2}, \mathrm{H}=2.5 \mathrm{~m}, \mathrm{Href}=0 \mathrm{~m}, 23 \mathrm{C}$

Exterior walls

1 Type 1 apartment, $\mathrm{W}=10 \mathrm{~m}, 180 \mathrm{deg}$, vert, $\mathrm{H}=2.5 \mathrm{~m}, \mathrm{Hfl}=0 \mathrm{~m}$,

3 windows (Type 1 exterior)

2 Vents (Type 1 shortlow; Type 2 shorthigh)

1 Exh fan

2 Type 1 apartment, $\mathrm{W}=15 \mathrm{~m}, 90 \mathrm{deg}$, vert, $\mathrm{H}=2.5 \mathrm{~m}, \mathrm{Hfl}=0 \mathrm{~m}$, 4 windows (Type 1 exterior)

2 vents (Type 3 longlow; Type 4 longhigh)

Interior walls

1 Type 3 stair, $\mathrm{W}=2.0 \mathrm{~m}$, Adj zone \#16 stair $1 \mathrm{st}, \mathrm{H}=2.5 \mathrm{~m}, \mathrm{Hfl}=0 \mathrm{~m}$

2 Type 1 apartment, $\mathrm{W}=13 \mathrm{~m}$, Adj zone $\# 29$ hall $1 \mathrm{st}, \mathrm{H}=2.5 \mathrm{~m}, \mathrm{Hfl}=0 \mathrm{~m}$ 1 Int door (Type 1 apartment)

3 Type 1 apartment, $\mathrm{W}=10 \mathrm{~m}$, Adj zone \#41 Apt $1 \mathrm{~A}, \mathrm{H}=2.5 \mathrm{~m}, \mathrm{Hfl}=0 \mathrm{~m}$

All other floor Apt B (southeast corner): $A=150 \mathrm{~m}^{2}, \mathrm{H}=2.5 \mathrm{~m}$,

Href $=2.5^{*}$ (Floor -1$) \mathrm{m}, 23 \mathrm{C}$

Exterior walls

1 Type 1 apartment, $\mathrm{W}=10 \mathrm{~m}, 180 \mathrm{deg}$, vert, $\mathrm{H}=2.5 \mathrm{~m}, \mathrm{Hfl}=0 \mathrm{~m}$,

3 windows (Type 1 exterior)

2 Vents (Type 1 shortlow; Type 2 shorthigh)

1 Exh fan

2 Type 1 apartment, $\mathrm{W}=15 \mathrm{~m}, 90 \mathrm{deg}$, vert, $\mathrm{H}=2.5 \mathrm{~m}, \mathrm{Hfl}=0 \mathrm{~m}$,

4 windows (Type 1 exterior)

2 Vents (Type 3 longlow; Type 4 longhigh) 
Interior walls

1 Type 3 stair, $\mathrm{W}=2.0 \mathrm{~m}$, Adj zone stairnth (from \#17 stair2nd), $\mathrm{H}=2.5 \mathrm{~m}$, $\mathrm{Hfl}=0 \mathrm{~m}$

2 Type 1 apartment, $W=13 \mathrm{~m}$, Adj zone hallnth (from $\# 30$ hall2nd), $H=2.5 \mathrm{~m}$, $\mathrm{Hfl}=0 \mathrm{~m}$

1 Int door (Type 1 apartment)

3 Type 4 floor, $W=10 \mathrm{~m}$, Adj zone apartment below (from \#53 Apt 1B), H=15 m, $\mathrm{Hfl}=0 \mathrm{~m}$

4 Type 1 apartment, $W=10 \mathrm{~m}$, Adj zone Apt A (from \#42 Apt $2 \mathrm{~A}$ ), $\mathrm{H}=2.5 \mathrm{~m}$, $\mathrm{Hfl}=0 \mathrm{~m}$

Apt C (northwest corner): $\mathrm{A}=150 \mathrm{~m}^{2}, \mathrm{H}=2.5 \mathrm{~m}$, Href $=2.5^{*}$ (Floor-1) $\mathrm{m}, 23 \mathrm{C}$

Exterior walls

1 Type 1 apartment, $\mathrm{W}=15 \mathrm{~m}, 270 \mathrm{deg}$, vert, $\mathrm{H}=2.5 \mathrm{~m}, \mathrm{Hfl}=0 \mathrm{~m}$, 4 windows (Type 1 exterior)

2 Vents (Type 3 longlow; Type 4 longhigh)

2 Type 1 apartment, $\mathrm{W}=10 \mathrm{~m}, 0 \mathrm{deg}$, vert, $\mathrm{H}=2.5 \mathrm{~m}, \mathrm{Hfl}=0 \mathrm{~m}$, 3 windows (Type 1 exterior)

2 Vents (Type 1 shortlow; Type 2 shorthigh)

1 Exh fan

Interior walls

1 Type 1 apartment, $W=13 \mathrm{~m}$, Adj zone hallnth (from $\# 30$ hall2nd), $H=2.5 \mathrm{~m}$, $\mathrm{Hfl}=0 \mathrm{~m}$

1 Int door (Type 1 apartment)

2 Type 2 elev, $\mathrm{W}=2.0 \mathrm{~m}$, Adj zone elevnth (from \#3 elev $2 \mathrm{nd}$ ), $\mathrm{H}=2.5 \mathrm{~m}, \mathrm{Hfl}=0 \mathrm{~m}$

3 Type 4 floor, $W=10 \mathrm{~m}$, Adj zone hall1st or Apt $\mathrm{C}$ below (from $\# 29$ hall1st or \#65 Apt 2C), $\mathrm{H}=15.0 \mathrm{~m}, \mathrm{Hfl}=0 \mathrm{~m}$

Apt $D$ (southwest comer): $A=150 \mathrm{~m}^{2}, \mathrm{H}=2.5 \mathrm{~m}, \mathrm{Href}=2.5^{*}$ (Floor-1) $\mathrm{m}, 23 \mathrm{C}$

Exterior walls

1 Type 1 apartment, $\mathrm{W}=10 \mathrm{~m}, 180 \mathrm{deg}$, vert, $\mathrm{H}=2.5 \mathrm{~m}, \mathrm{Hfl}=0 \mathrm{~m}$,

3 windows (Type 1 exterior)

2 Vents (Type 1 shortlow; Type 2 shorthigh)

1 Exh fan

2 Type 1 apartment, $\mathrm{W}=15 \mathrm{~m}, 270 \mathrm{deg}$, vert, $\mathrm{H}=2.5 \mathrm{~m}, \mathrm{Hfl}=0 \mathrm{~m}$, 4 windows (Type 1 exterior)

2 Vents (Type 3 longlow; Type 4 longhigh) 
Interior walls

1 Type 3stair, $\mathrm{W}=2.0 \mathrm{~m}$, Adj zone staimth (from \#17 stair2nd), $\mathrm{H}=2.5 \mathrm{~m}$, $\mathrm{Hfl}=0 \mathrm{~m}$

2 Type 1 apartment, $\mathrm{W}=13 \mathrm{~m}$, Adj zone hallnth (from \#30 hall2nd), $\mathrm{H}=2.5 \mathrm{~m}$, $\mathrm{Hfl}=0 \mathrm{~m}$

1 Int door (Type 1 apartment)

3 Type 1 apartment, $\mathrm{W}=10 \mathrm{~m}$, Adj zone Apt $\mathrm{C}$ (from \#65 Apt 2C), $\mathrm{H}=2.5 \mathrm{~m}$, $\mathrm{Hfl}=0 \mathrm{~m}$

4 Type 4 floor, W=10 m, Adj zone hall1st or Apt D below (from \#29 hall1st or \#76 Apt 2D), $\mathrm{H}=15 \mathrm{~m}, \mathrm{Hfl}=0 \mathrm{~m}$

Basement: $A=665 \mathrm{~m}^{2}, \mathrm{H}=2.5 \mathrm{~m}, \mathrm{Href}=-2.5 \mathrm{~m}, 23 \mathrm{C}$

Exterior walls

1 Type 1 apartment, $\mathrm{W}=30 \mathrm{~m}, 90 \mathrm{deg}$, vert, $\mathrm{H}=0.5 \mathrm{~m}, \mathrm{Hfl}=2.0 \mathrm{~m}$, 6 windows (Type 2 basement)

2 Type 1 apartment, $\mathrm{W}=30 \mathrm{~m}, 270 \mathrm{deg}$, vert, $\mathrm{H}=0.5 \mathrm{~m}, \mathrm{Hfl}=2.0 \mathrm{~m}$, 6 windows (Type 2 basement)

Interior walls

1 Type 2 elev, $\mathrm{W}=2.0 \mathrm{~m}$, Adj zone \#1 elevbase, $\mathrm{H}=2.5 \mathrm{~m}, \mathrm{Hfl}=0 \mathrm{~m}$

2 Type 2 elev, $\mathrm{W}=2.0 \mathrm{~m}$, Adj zone \#1 elevbase, $\mathrm{H}=2.5 \mathrm{~m}, \mathrm{Hfl}=0 \mathrm{~m}$

3 Type 2 elev, $\mathrm{W}=2.5 \mathrm{~m}$, Adj zone \#1 elevbase, $\mathrm{H}=2.5 \mathrm{~m}, \mathrm{Hfl}=0 \mathrm{~m}$ 1 Int door (Type 2 elevator)

4 Type 3 stair, $W=2.0 \mathrm{~m}$, Adj zone \#15 stairbase, $\mathrm{H}=2.5 \mathrm{~m}, \mathrm{Hfl}=0 \mathrm{~m}$

5 Type 3 stair, $\mathrm{W}=2.0 \mathrm{~m}$, Adj zone \#15 stairbase, $\mathrm{H}=2.5 \mathrm{~m}, \mathrm{Hfl}=0 \mathrm{~m}$

6 Type 3 stair, $\mathrm{W}=2.5 \mathrm{~m}$, Adj zone \#15 stairbase, $\mathrm{H}=2.5 \mathrm{~m}, \mathrm{Hfl}=0 \mathrm{~m}$ 1 Int door (Type 3 stair)

7 Type 4 floor, $\mathrm{W}=10 \mathrm{~m}$, Adj zone \#41 Apt $1 \mathrm{~A}, \mathrm{H}=15 \mathrm{~m}, \mathrm{Hfl}=2.5 \mathrm{~m}$

8 Type 4 floor, $\mathrm{W}=10 \mathrm{~m}$, Adj zone \#53 Apt $1 \mathrm{~B}, \mathrm{H}=15 \mathrm{~m}, \mathrm{Hfl}=2.5 \mathrm{~m}$

9 Type 4 floor, $\mathrm{W}=10 \mathrm{~m}$; Adj zone \#29 hall1st, $\mathrm{H}=36.5 \mathrm{~m}, \mathrm{Hfl}=2.5 \mathrm{~m}$ 
CONTAM88 has two options for modeling ventilation system airflows. One option is to input a fixed outdoor airflow rate into or an exhaust airflow rate out of a building zone. This option is useful for modeling a simple exhaust fan in a bathroom or kitchen for example. The second option for modeling mechanical ventilation is to create a so-called HVAC system in the model, similar to a building zone. Each HVAC system can be connected to any number of building zones by HVAC supply or return vents, each associated with a specific airflow rate. The HVAC system option is useful for representing a system that serves several rooms or a system for which the percent outdoor air intake will be varied in different CONTAM88 runs.

The first option is implemented in NBSAVIS after the rooms have been defined. One identifies the rooms that will contain a fixed mechanical airflow, whether it is a supply or return (or exhaust) flow, and the airflow rate associated with each flow. In NBSAVIS, under Type Component Library Data, one selects Fixed Flows. Each airflow rate identified is entered in the Fixed Flows table with a Flow Name and a Flow Rate. The mechanical flows are entered under Physical Building Data by selecting Room Data and then selecting any exterior wall. Fixed mechanical flows can only be entered in exterior walls, and it does not matter which exterior wall is used in a room with more than one exterior wall. If one wishes to enter a fixed mechanical flow in a room without any exterior walls, one can add an exterior wall with zero leakage and locate the flow in that "dummy" exterior wall. Under Exterior Wall Data, one selects "Number of outside supply fans" to enter a supply flow or "Number of exhaust fans" to enter an exhaust flow. In either case, one inputs the number from the Fixed Flows table that corresponds to the desired mechanical flow rate.

The HVAC system option is implemented by inputting the number of HVAC systems that will be modeled under Number of HVAC Systems in the Building Descriptions menu. A single HVAC system is used to model a ducted exhaust or supply system. Two HVAC systems are used to model a system that can recirculate return air into the supply airstream. It is convenient to use the terms Supply and Return in the names of these systems. The HVAC System Data menu is used to describe each HVAC system in terms of its volume, number of contaminant sources and kinetic reaction number as described in the CONTAM88 user's manual.

In addition to defining and describing the HVAC systems, one must identify the individual supply and return airflow rates into and out of each room as well as the fraction of the return air that will be recirculated. These airflow rates must be input into the Fixed Flows menu as described above. The airflow rates entered in the menu should include separate entries for the airflow rate of return air that will be recirculated and the airflow rate of return air that will be exhausted to the outdoors. Under the Room Data menu, one then selects "Number of supplies" and "Number of returns". A fixed flow is entered for each supply vent and each return vent. Two return vents are entered for each return vent when some of the return air is recirculated. In each case, one specifies the Fan Number of the 
HVAC system associated with the airflow rate, the Type Number corresponding to the Fixed Flows menu, the Filter Number if there is a filter in the vent, the Number of Fans if there is more than one vent of this type in the room, and the Height above Floor. The last item is not currently used by CONTAM88 and any numerical value can be entered.

After all of the HVAC systems and vents are entered with NBSAVIS, Calculate Building Zone \& Opening Data in the Main Menu is selected to perform a mass balance of each system and to produce the files needed for execution of CONTAM88. For each HVAC system, all the supply airflows out of the system are added together and all of the return airflows are subtracted. If there is an imbalance between the total supply and return airflow rates, it is compensated for with outdoor air intake or exhaust to the outdoors as appropriate. In this way, one can use an HVAC system to bring varying amounts of outdoor air into the building. The intake rate is varied by changing the return airflow rates to the return HVAC system and the supply HVAC system. 
Appendix D. User Manual NBSAVIS CONTAM88 Errata Sheet

Page 1: In figure 1 change "CONTAM88.DAT" and "CONTAM.DAT" to "CONTAM88.DTA" and "CONTAM.DTA".

Page 9: Change Section 2.37 "Miscellaneous Leakage Types" to "Miscellaneous Opening Types".

Page 30: Paragraph 1, line 2, change "Table 3" to "Table 7". Paragraph 2, line 2, change "Tables 3 to 10 " to "Tables 8 to 16 ".

Page 31: Last paragraph, line 1, "Change Building Parameters" to "Change Program Parameters".

Page 34: Last paragraph, change lines 1 and 2, change "Table 14" to "Table 18". Line 3, change "Table 15" to "Table 19".

Page 35: Paragraph 1, line 2, change "Figure 21" to "Figure 20". Paragraph 2, line 1, change "Table 16" to "Table 20". Line 4, change "F6" to "F5".

Page 36: Paragraph 1, line 2, change "F9" to "F5". Paragraph 2, lines 1 and 2, change "Table 25" and "F8" to "Table 29" and "F7".

Page 52: Line 2, change "Table 27" to "Table 30".

Page 60: Last paragraph, last line, change "Table 30" to "Table 46".

Page 71: Third Table, change "Po214-u" to Pb214"u".

Page 73: Table, change "Bi218-a" to "Bi214"-a".

Page 89: Section 4.5, lines 2 and 11, change the file name "TRANSIENT.PLT" to "TRANS.PLT". 

